ORNL/TM-13019

\author{
Preliminary Evaluation of \\ Electrowinning for \\ Nickel Scrap Processing
}
G. M. Brown
A. L. Compere
W. L. Griffith
H. W. Hayden
D. F. Wilson

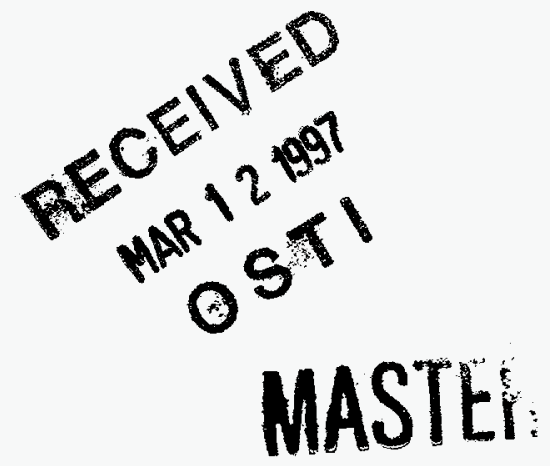

TMICED WWO OPERTEO BY LOCKHEEO WARTI ENERGY RESEARCH CORPORMION FOA THE UNIEO STATES DEPAMUENT OF EMERGY 
This report has been reproduced directly from the best available copy.

Available to DOE and DOE contractors from the Office of Scientific and Technical

Information, P.O.Box 62, Oak Ridge, TN 37831; prices available from (423) 576-8401, FTS 626-8401.

Available to the public from the National Technical Information Service, U.S. Department

of Commerce, 5285 Port Royal Rd., Springfield, VA 22161

This report was prepared a an account of work sponsored by an agency of the United States Government. Neither the United States Government nor any agency thereof, nor any of their employees, makes any warranty, express or implied, or assumes any legal liability or responsibility for the accuracy. completeness, or usefulness of any information, apparatus, product, or process disclosed, or represents that its use would not infringe privately owned rights. Reference herein to any specific commercial product, process, or service by trade name, trademark, manufacturer, or otherwise, does not necessarily constitute or imply its endorsement, recommendation, or favoring by the United States Government or any agency thereof. The view and opinions of authors expressed herein do not necessarily state or reflect those of the UnitedStatesGovernment or any agency thereot. 


\section{DISCLAIMER}

Portions of this document may be illegible electronic image products. Images are produced from the best available original document. 
ORNL/TM-13019

\title{
Preliminary Evaluation of Electrowinning for Nickel Scrap Processing
}

\author{
G. M. Brown \\ A. L. Compere \\ W. L. Griffith \\ H. W. Hayden \\ D. F. Wilson
}

Prepared by the Oak Ridge National Laboratory

Oak Ridge, Tennessee 37831 managed by

Lockheed Martin Energy Systems

for the

U. S. Department of Energy

under Contract No. DE-AC05-960R22464

Date Published: December 1996 



\section{Contents}

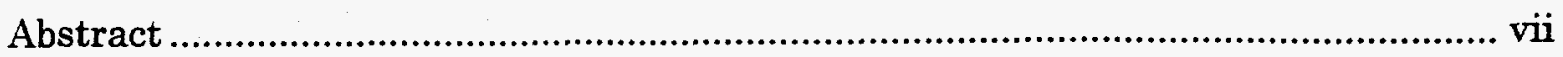

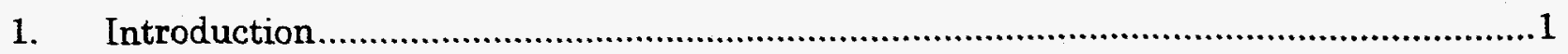

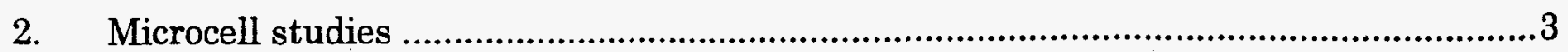

Buffered $1 M$ nickel sulfate with $0.5 M$ sodium chloride ........................................4

Buffered $1 M$ nickel sulfate with $1.5 M$ sodium chloride …....................................5

$1 M$ Nickel chloride ......................................................................................

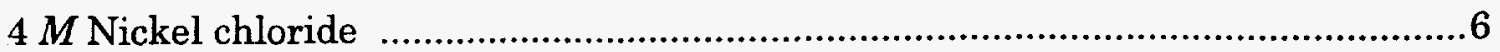

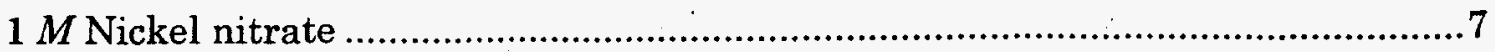

$1 M$ Nickel chloride with $0.5 \mathrm{M}$ ammonium thiocyanate .....................................

$1 M$ Nickel chloride with $0.5 M$ ammonium chloride .............................................. 8

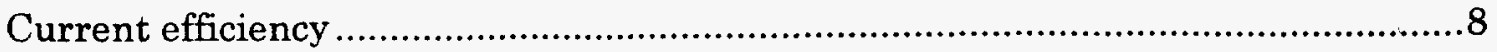

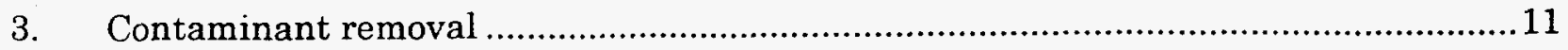

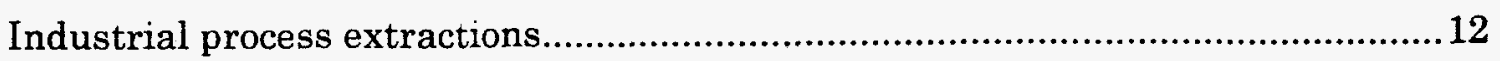

Technetium and actinide extractions ...........................................................14

Ion exchange separations ....................................................................................17

Backwashing and stripping of radiological contaminants from extractants..........17

Confirmation of contaminant removals .............................................................18

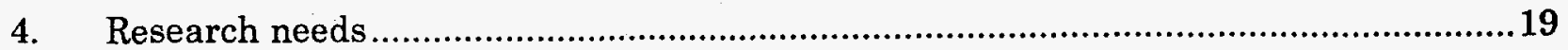

Separation needs ...........................................................................................19

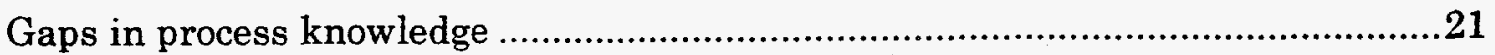

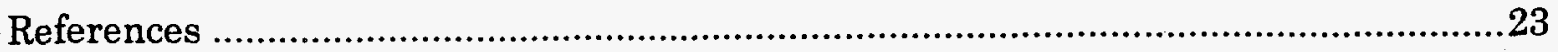

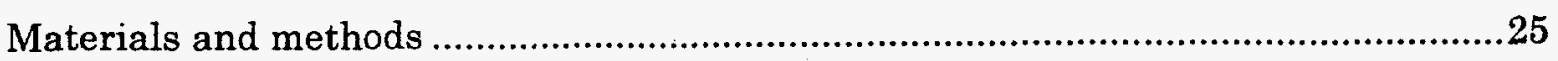

\section{Tables}

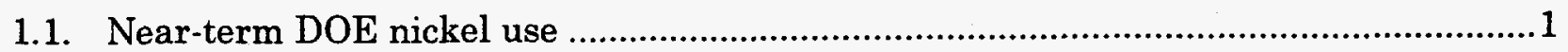

1.2. Estimated long-term DOE nickel use in stainless steel ..............................................

2.1. Current efficiencies from microcell plating tests. .........................................................9

3.1. Radiological analyses of 30 individual Paducah nickel ingots.....................................11

3.2. Regulatory requirements for export ....................................................................12

3.3. Parameters for extractive separations of base metals ................................................12

3.4. Trends in actinide extraction by alkyl ammonium salts .............................................14

3.5. Solvent extraction of technetium and uranium from acid solutions ............................15

3.6. Distribution of pertechnate between organic and neutral aqueous phases at $25 \mathrm{C}$....18 


\section{Figures}

2.1. Three compartment microcell

2.2. Potentiometric scan of buffered $1 M$ nickel sulfate $-0.5 M$ sodium chloride electrolyte 4

2.3. Nickel plate from $1 M$ nickel sulfate $-0.5 \mathrm{M}$ sodium chloride electrolyte at high current density.

2.4. Nickel plated from $1 M$ nickel sulfate $-0.5 M$ sodium chloride electrolyte at low current density

2.5. Potentiometric scan of buffered $1 M$ nickel sulfate $-1.5 M$ sodium chloride electrolyte 5

2.6. Nickel plate from $1 M$ nickel sulfate - $1.5 M$ sodium chloride electrolyte 5

2.7. Potentiometric scan of $1 M$ nickel chloride electrolyte... .5

2.8. Nickel plate from $1 M$ nickel chloride electrolyte at high current density 6

2.9. Nickel plate from $1 M$ nickel chloride electrolyte at low current density. 6

2.10. Potentiometric scan of $4 M$ nickel chloride electrolyte. 6

2.11. Nickel plate from $4 M$ nickel chloride electrolyte at high current density 7

2.12. Potentiometric scan of $1 M$ nickel nitrate electrolyte. 7

2.13. Nickel plate from $1 M$ nickel nitrate electrolyte. 7

2.14. Potentiometric scan of $1 M$ nickel chloride $-0.5 M$ ammonium thiocyanate electrolyte 8

2.15. Plate from $1 M$ nickel chloride $-0.5 M$ ammonium thiocyanate electrolyte 8

2.16. Potentiometric scan from $1 M$ nickel chloride $-0.5 M$ ammonium chloride electrolyte .9

2.17. Plate from $1 \mathrm{M}$ nickel chloride - $0.5 \mathrm{M}$ ammonium chloride electrolyte .....................9

4.1. Falconbridge Nickel Refinery chlorine-based process ............................................20

4.2. Proposed nickel electrowinning process..................................................... 21

4.3. Theoretical stages required to strip $2650 \mathrm{~Bq} / \mathrm{g}{ }^{99} \mathrm{Tc}$ from nickel electrolyte at $K_{d}=50$ 21 


\title{
Preliminary Evaluation of Electrowinning for Nickel Scrap Processing*
}

\author{
G. M. Brown \\ A. L. Compere \\ W. L. Griffith \\ H. W. Hayden \\ D. F. Wilson
}

\begin{abstract}
Purification of the 70,000 to 245,000 tons of diffusion plant nickel scrap permit its use in a variety of $\mathrm{DOE}$ and, with establishment of de minimus standards, foreign and domestic industrial applications. Nickel recycle would also substantially decrease DOE legacy wastes. This report presents data on electrolytes and separations which could be used in electrolytic purification of radiologically contaminated nickel scrap from first generation diffusion plants. Potentiometric scans and plating tests indicate that both industrial electrolytes, buffered nickel sulfate - sodium chloride and nickel chloride, provide good current densities. Electrolytes which contain ammonium thiocyanate or ammonium chlorde also perform well. Nickel does not plate appreciably from nitrate solutions because the nitrate was preferentially reduced to nitrite. Solvent extractions of cobalt, a common contaminant in commercial nickel, and pertechnate, a radiological contaminant expected in DOE nickel scrap, are also successful.
\end{abstract}

\footnotetext{
*Research sponsored by the Office of Technology Development, U. S. Department of Energy, under contract DE-AC05-960R22464 with Lockheed Martin Energy Research Corp.
} 


\section{Introduction}

As indicated in an earlier project report, Contaminated nickel scrap processing, conventional nickel processing technologies have the potential for application in recovery of radiologically contaminated nickel. Because the amounts of contaminated nickel are estimated to be between 70,000 and 245,000 (Kessinger 1993) tons, this could minimize legacy wastes. As nickel is a relatively scarce strategic metal purchased from a variety of foreign sources, development and demonstration of integrated technologies for its recovery would contribute to national security.

Several routes for reuse of nickel are available. After decontamination and any necessary declassification, purified nickel could be sold for industrial use. This approach will be feasible only in countries, such as Spain, where de minimus standards permit use of recovered nickel. In the U. S., nickel recycle is limited by current DOE standards for domestic public resale which require the absence of even those levels of contaminants found in virgin conventional nickel (Science Applications International Corporation 1995).

Nickel has been used extensively in nuclear applications because of its resistance to $\mathrm{HF}$ and $\mathrm{UF}_{6}$. As shown in Table 1.1, a substantial amount of scrap nickel could be used by DOE in the next few years, primarily to for waste storage and transportation containers and for $\mathrm{UF}_{6}$ cylinders (Barber et al 1991, 1994). DOE in-house use of nickel may minimize decontamination because the metal used in, for example, burial containers, could be required only to meet disposal standards.

Table 1.1. Near-term DOE nickel use

\begin{tabular}{lcrrr}
\hline Use & Steel & Number & Weight, Ib & Ni, tons \\
\hline B-25 boxes & 304 & 200,000 & 800 & 6,400 \\
Casks for WIPP & 304,316 & 36 & 12,250 & 18 \\
UF6 cylinders & 304 & 47,000 & 2,590 & 4,869 \\
Total & & & & 11,287 \\
\hline
\end{tabular}

In the long term, DOE could also choose to use stainless steel containers made with scrap nickel. These would replace the current and planned mild steel waste disposal containers and structural supports. As shown in Table 1.2, DOE could use 200,000 tons of nickel.

The advantages to DOE include lower long-term maintenance costs and a reduced probability of container breaches due to corrosion. Although DOE could, by in-house use, consume the bulk of the nickel scrap estimated to be available in DOE facilities, it is more likely that DOE will recycle nickel scrap only for selected uses and will need to develop alternative uses or resale strategies for remaining nickel scrap.

Nickel, by its nature, lends itself well to purification and recycle. It is unique in the high purity of standard commercial stock. Electrorefining and electrowinning production facilities typically use a combination of voltage control, selective precipitation and, more recently, solvent extraction, to achieve these levels of purity. Although basic processing technologies follow a

Table 1.2. Estimated long-term DOE nickel use in stainless steel

\begin{tabular}{lrrr}
\hline Use & Number & Weight, Ib & Ni, tons \\
\hline Reinforcing bar and mats & & $200,000,000$ & 8,000 \\
Shielding blocks & 300,000 & 2,000 & 24,000 \\
Transportation and disposal boxes & $1,000,000$ & 1,000 & 40,000 \\
Transportation and disposal drumes & $50,000,000$ & 50 & 100,000 \\
Type A shipping casks & 30,000 & 10,000 & 12,000 \\
Vitrification canisters & 30,000 & 3,000 & $\underline{3,600}$ \\
Total & & & 187,600 \\
\hline
\end{tabular}

Source: Scientific Ecology Group, Inc. 
similar pattern, each refining operation uses a unique combination of steps to remove nickel contaminants. The nickel is then recovered by plating.

The high volume of DOE scrap encourages the evaluation of adaptations which permit use of conventional industrial processes for nickel recovery. Much of the DOE radiologically contaminated scrap is high purity nickel contaminated by small amounts of: ${ }^{234} \mathrm{Th},{ }^{234} \mathrm{~Pa}$, ${ }^{137} \mathrm{Cs},{ }^{239} \mathrm{Pu}$ (trace), ${ }^{60} \mathrm{Co}, \mathrm{U},{ }^{99} \mathrm{Tc}$, and ${ }^{237} \mathrm{~Np}$ (trace). However, if resale for public use is planned, nickel would have to meet the de minmus requirements discussed in Chapter 3 , Contaminant removal. As a part of these requirements, certain uses are also limited. These goals will require development of side-stream purification processes which are both extremely effective and extremely selective for the radiological species of interest. However, conventional nickel electrowinning and electrorefining processes use complicated electrolytes to produce high-quality nickel plates and to recover other ore or matte metals. The complex chemistry of these solutions typically renders them unsuitable for use as electrolytes for ion exchange and solvent extraction. Adaptation of conventional processing technology to DOE nickel scrap recycle will require simplification of the process streams and of the processes themselves, together with enhancement of processes for trace element removal.

There were several reasons for evaluating electrolyte and separations systems at the small bench scale. A number of integrated solvent extraction and electrowinning or electrorefining systems have been proposed by various groups. The advantages and disadvantages of each are peculiar to their chemistry. For example, uranium processing and separations have traditionally used nitrate-based systems. Use of a nitrate electrolyte system would permit adaptation of a wide variety of standard solvent extraction and separations technologies for sidestream processing. However, there is no reported industrial experience with nitrate electrolyte systems for nickel electrorefining or electrowinning, and nitrate is readily reduced to nitrite. The opposite situation exists with chloride electrolyte systems: nickel producers are gradually replacing sulfate - chloride borate electrolytes for nickel electrowinning and electrorefining. Additionally, it is possible that the solvent extractions could be optimized to remove radiological contaminants. However, experience with chloride-based separations of radiological constituents is limited in practice. The very low levels of contaminants - typically parts per million - in nickel which otherwise exceeds conventional commercial purity encourages evaluation of ion exchange and other techniques typically used for trace element removal. In each case, evaluation of small-scale process data was needed to as a basis for selection of a process scheme capable of both recovering pure nickel and removing radiological constituents.

This report presents data obtained in small bench scale evaluations of electrolytes and separations methods which could be used for electrorefining or electrowinning nickel from DOE-produced scrap. The electrode studies were conducted to evaluate polarization, current efficiency, and quality of plating from conventional and proposed electrolyte solutions. Evaluations of metal deposit quality and quantity were also conducted using small nickel electrodes. Solvent extraction, singly and in combination with complexation, was evaluated for removal of ${ }^{99} \mathrm{Tc}$, a contaminant of particular concern, and cobalt, a material typically removed during conventional nickel electrorefining. Ion exchange separations were also evaluated. 


\section{Microcell Studies}

Electrolytes of potential use for recovery of scrap nickel were evaluated as described in Materials and Methods. A schematic of the three compartment cell used for these studies is shown in Fig. 2.1. The design incorporated a $1 \mathrm{~mm}$ nickel wire working electrode, a 2 $\mathrm{mm}$ nickel wire ancillary electrode, and a standard calomel reference electrode. For current efficiency and plating studies, the working electrode was replaced by a $1 \mathrm{~cm}^{2}$ by 2 $\mathrm{mm}$ thick nickel plate attached to a $1 \mathrm{~mm}$ nickel wire. A personal computer and a potentiostat interactively controlled and recorded inputs and outputs.

Electrolytes evaluated included nitrate as well as conventional industrial electrorefining and electrowinning chloride and buffered sulfate-chloride. A nitrate electrolyte was evaluated even though there are few literature reports of its use in nickel electrolysis because nitrate solutions are extensively used in radiological separations. Electrolytes with ammonium thiocyanate and ammonium chloride were also evaluated to asses the possibility of enhancing separations with selective complex formation. Formation of nickel thiocyanate complexes is limited. Thus, extraction of thiocyanate complexes has historically been used to separate impurities from nickel (Griffith, Jasny, and Tupper 1952).

Electrode polarization, plating quality, and plating current

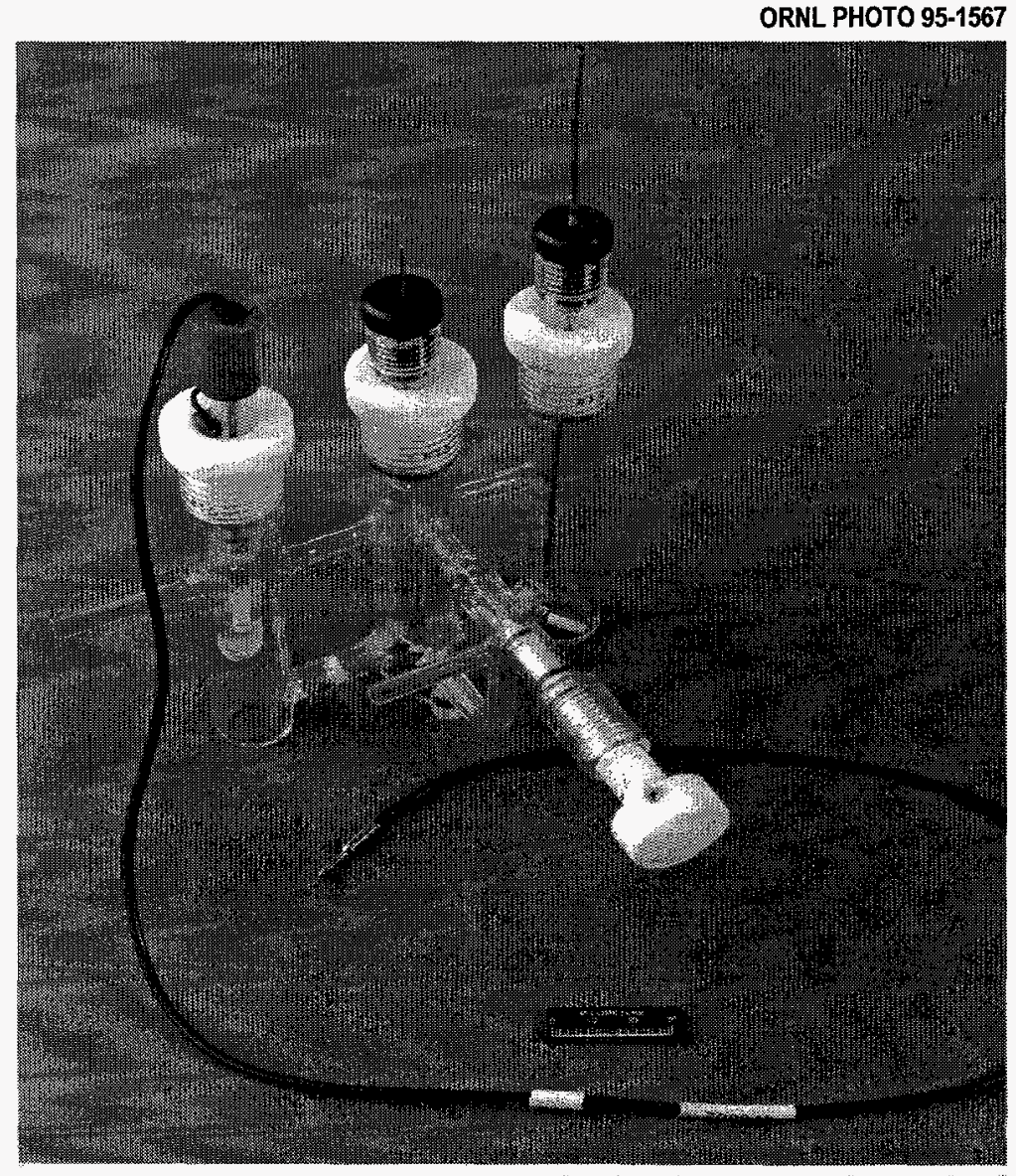

Fig. 2.1. Three compartment microcell. efficiency were evaluated using the microcell. Results obtained with each of the electrolytes are presented below. Comparative current efficiencies follow. Potentiometric scans were repeated several times to ensure that the data were both representative and consistent. The major emphasis in this portion of the study has been development of an understanding of reactions and side-reactions in proposed electrolyte systems. This is important because a significant side reaction could make nickel deposition or production of a nickel electrode of acceptable purity from a given electrolyte impossible. 


\section{Buffered $1 M$ nickel sulfate with $0.5 M$ sodium chloride}

Potentiometric scans. Conventional industrial processes have historically used an electrolyte containing nickel sulfate and sodium chloride buffered with boric acid. Although this electrolyte is gradually being replaced by nickel chloride, it has a long history of consistent successful use. This is evident in Fig. 2.2, a composite curve including both positive and negative scans. As can be noted from the smooth curve, there were no significant competing reactions. Also, no gas bubbles were observed during the experiment.

Plating. Current efficiencies of roughly 95\% were obtained at both high and low current densities. The plating obtained under high current density conditions, Fig. 2.3 , was less uniform than that obtained under low current density conditions, Fig. 2.4. In both cases, pits were observed in the plating. The plating delaminated from the substrate and exhibited the typical nickel plating microstructure.

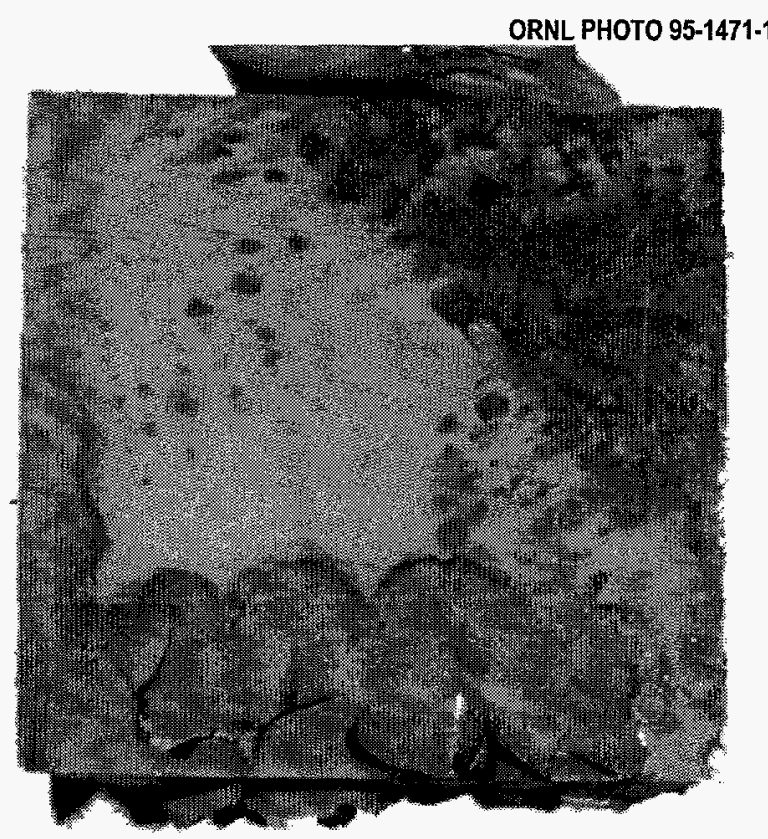

Fig. 2.3. Nickel plate from $1 M$ nickel sulfate -0.5 $M$ sodium chloride electrolyte at high current density.

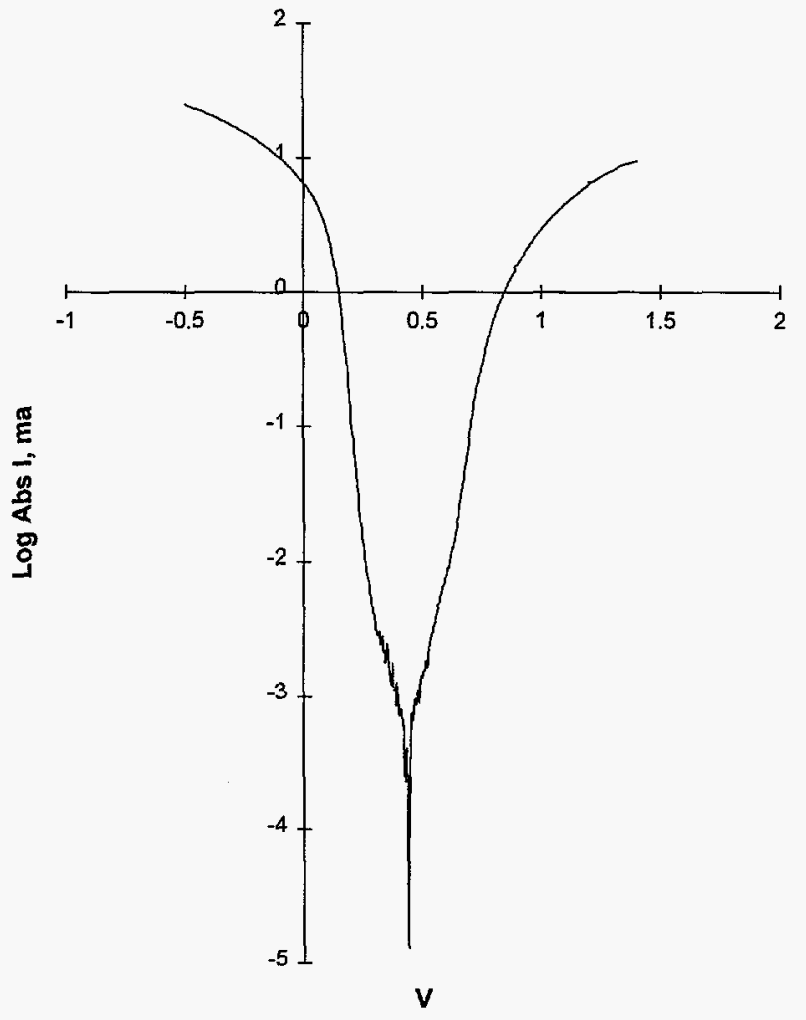

Fig. 2.2. Potentiometric scan of $1 M$ buffered nickel sulfate $-0.5 \mathrm{M}$ sodium chloride electrolyte.

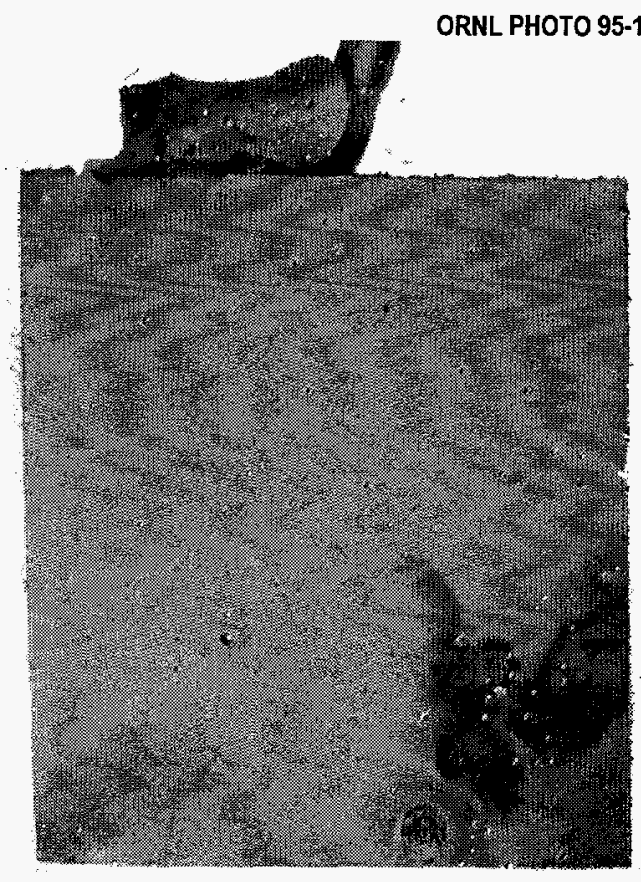

Fig. 2.4. Nickel plate from $1 M$ nickel sulfate $0.5 M$ sodium chloride electrolyte at low current density. 


\section{Buffered $1 M$ nickel sulfate with $1.5 M$ sodium chloride}

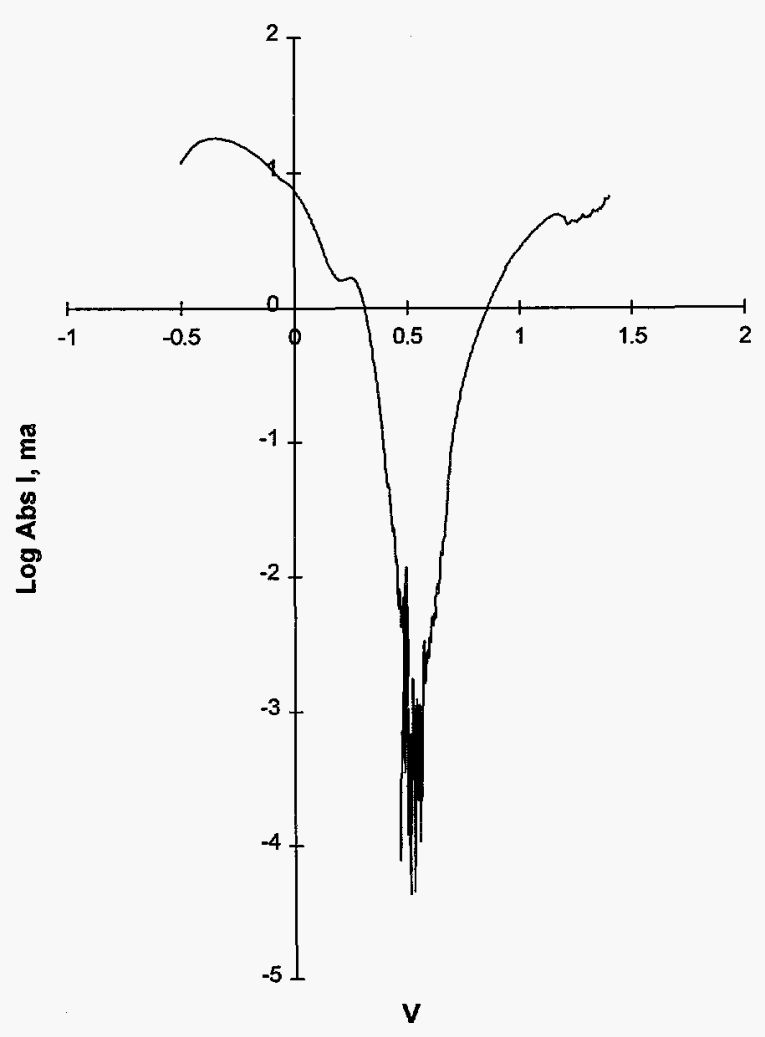

Fig. 2.5. Potentiometric scan of buffered $1 M$ nickel sulfate $-1.5 \mathrm{M}$ sodium chloride electrolyte.

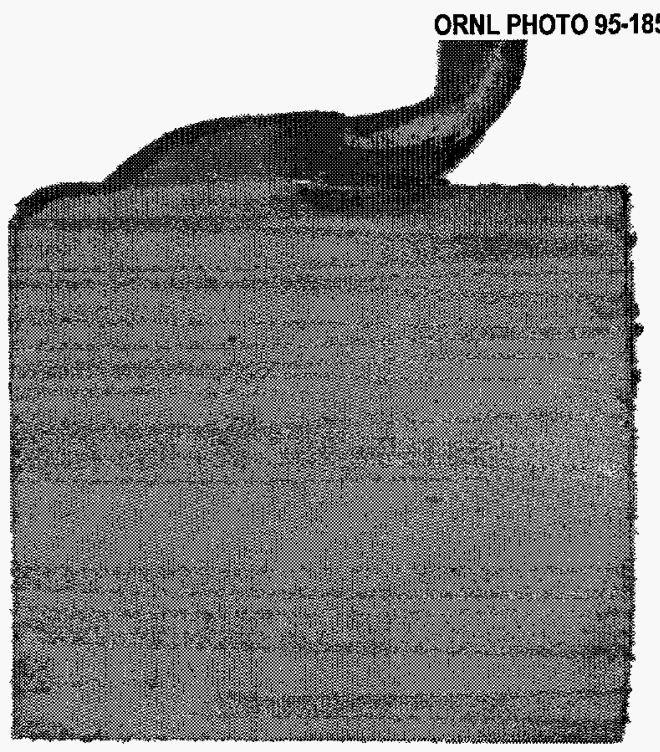

Fig. 2.6. Nickel plate from $1 M$ nickel sulfate $1.5 M$ sodium chloride electrolyte.
Potentiometric scans. Some buffered sulfate electrolytes used for industrial nickel electrolysis contain $1.5 M$ sodium chloride. A composite curve including both positive and negative scans for this electrolyte is shown in Fig. 2.5. As with the $0.5 M$ sodium chloride electrolyte discussed above, the smooth curves for this system indicate no significant competing reactions.

Plating. This electrolyte, as shown in Fig. 2.6, gave a dense, adherent plating. Coupled with the high current density, $98 \%$, this indicates why this electrolyte system has found extensive commercial use.

\section{$1 M$ nickel chloride}

Potentiometric scans. The composite curve for a $1 M$ nickel chloride system is shown in

Fig. 2.7. The curve indicates the possibility of

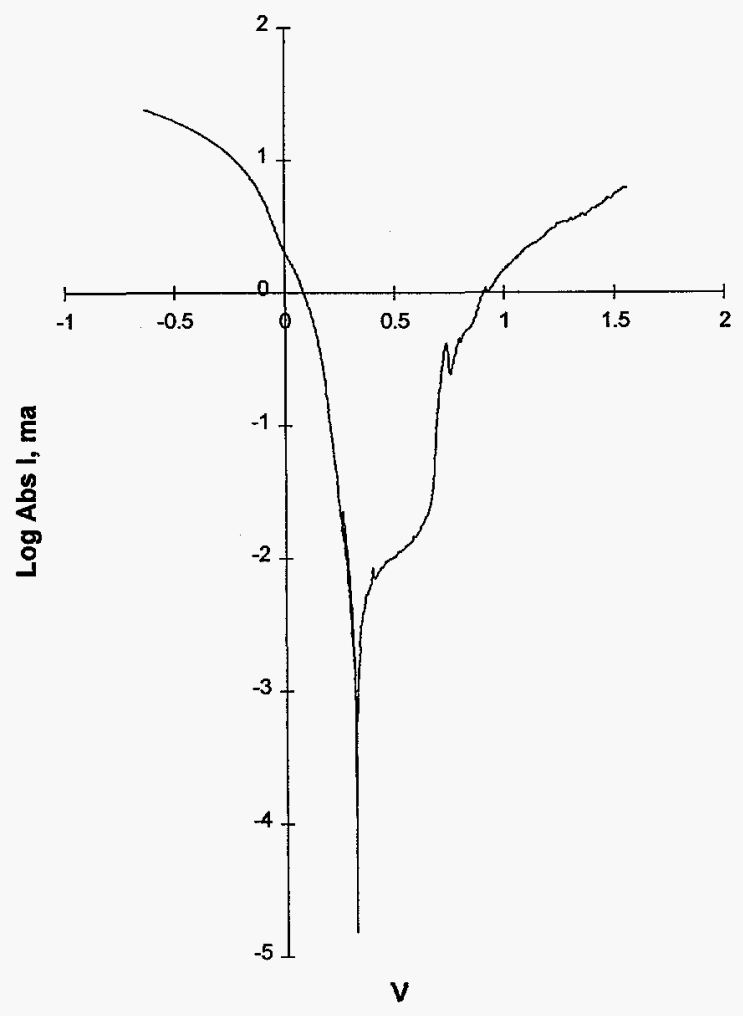

Fig. 2.7. Potentiometric scan of $1 M$ nickel chloride electrolyte. 
a minor competing reaction. However, at the levels indicated by the slight change in curvature, it is reasonable to expect that this could be controlled by minor adjustments in electrolyte composition or buffering. Nickel chloride is currently used in industrial nickel electrowinning systems.

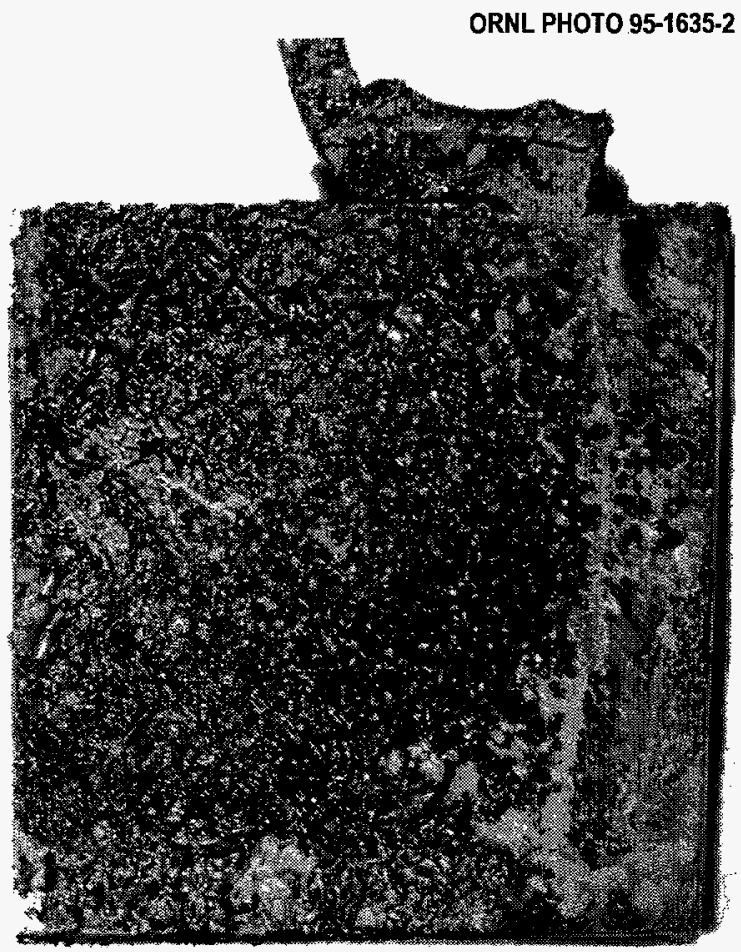

Fig. 2.8. Nickel plate from $1 M$ nickel chloride electrolyte at high current density.

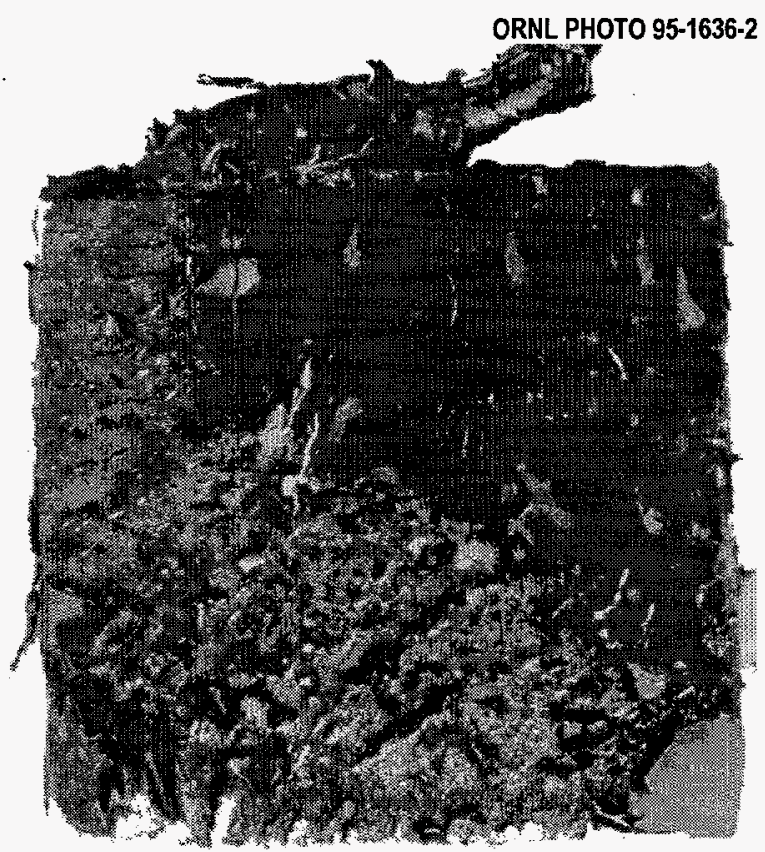

Fig. 2.9. Nickel plate from $1 M$ nickel chloride electrolyte at low current density.
Plating. Currrent efficiencies obtained for the $1 M$ chloride system were $72-81 \%$, substantially lower than those obtained for the conventional sulfate - chloride electrolyte. However, gas bubble formation was observed during the plating tests. The plate produced at high current density is shown in Fig. 2.8 and that at low current density, in Fig. 2.9.

\section{$4 M$ nickel chloride}

Potentiometric scans. The composite curve for the $4 M$ nickel chloride system is shown in Fig. 2.10. The smooth curve indicate that there are no significant competing reactions. Although $4 M$ is higher than the levels used in conventional industrial systems, the use of a higher concentration electrolyte could be advantageous in improving the separations of radiological contaminants by increasing salting out into solvent extractants.

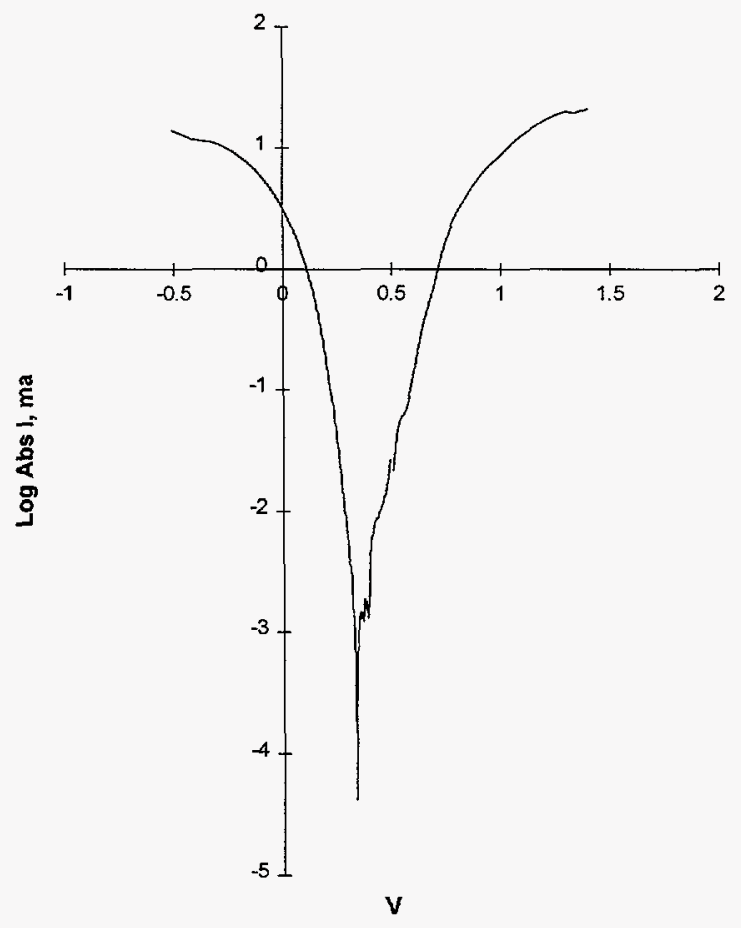

Fig. 2.10. Potentiometric scan of $4 M$ nickel chloride electrolyte. 


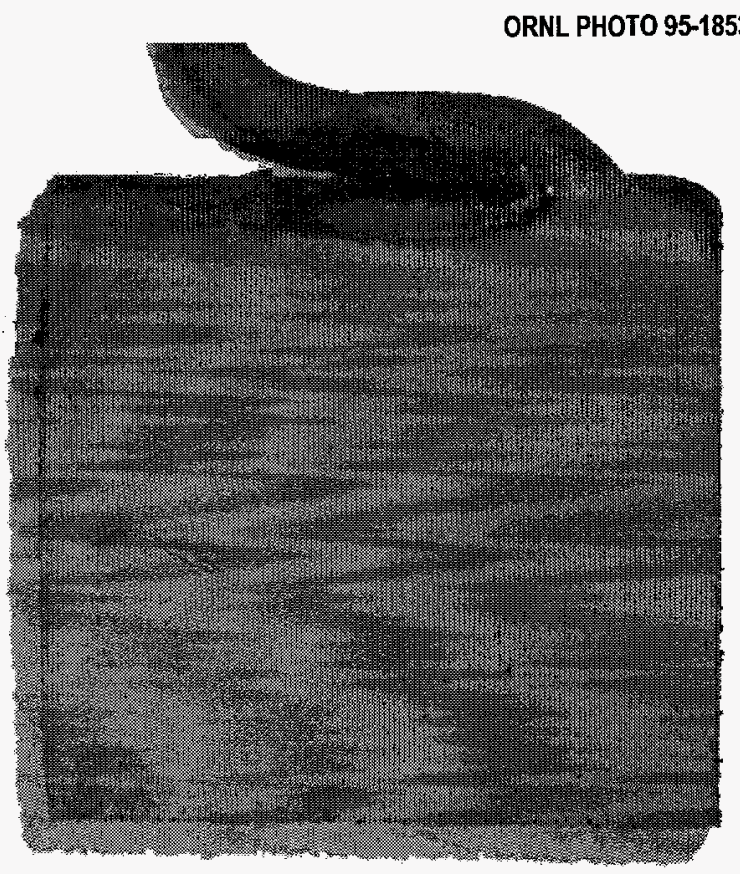

Fig. 2.11. Nickel plate from $4 M$ nickel chloride electrolyte at high current density.

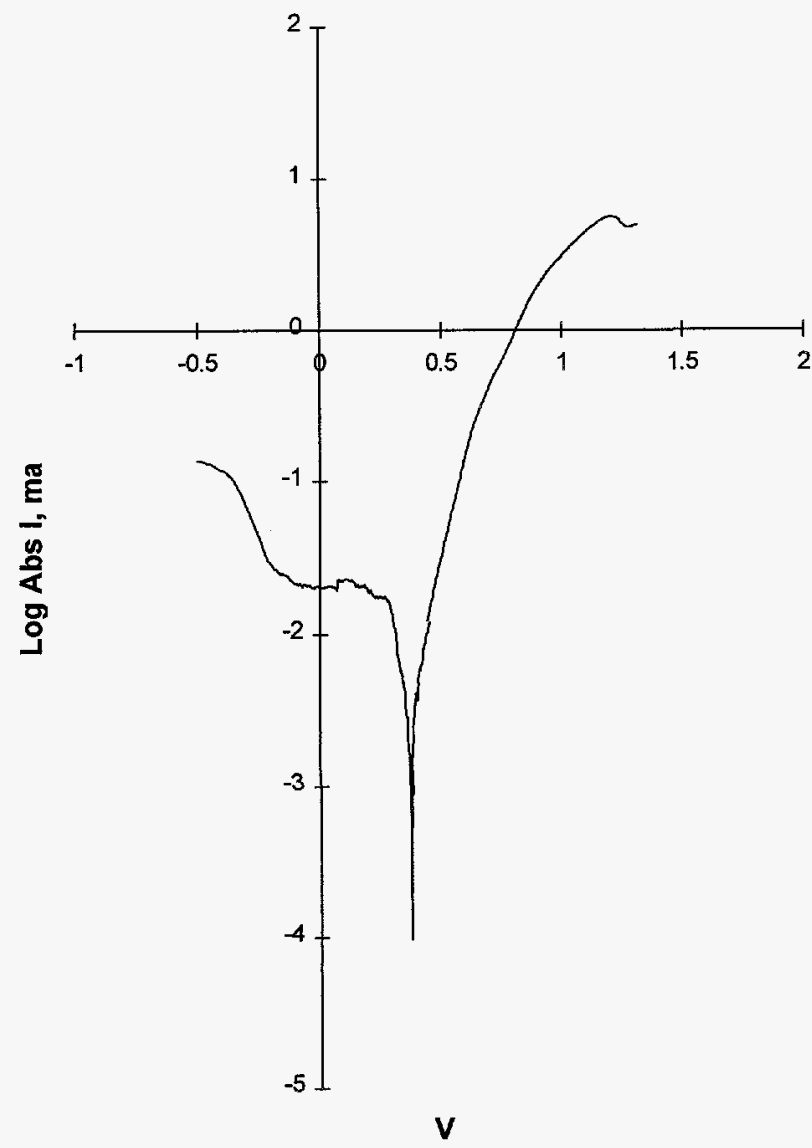

Fig. 2.12. Potentiometric scan of $1 M$ nickel nitrate electrolyte.
Plating. The plate produced from this electrolyte, shown in Fig. 2.11, is dense, smooth, and adherent. Morphology, coupled with the high current density, $99.8 \%$, indicate that this electrolyte should receive further evaluation.

\section{$1 M$ Nickel nitrate}

Potentiometric scans. The composite curve for $1 M$ nickel nitrate electrolyte is shown in Fig. 2.12. As shown, there is a strongly competing reaction. Subsequent analysis of the electrolyte solution indicated this reaction to be the reduction of nitrate to nitrite. Unless a method for inhibiting nitrate reduction can be developed, this electrolyte cannot be used for electrolytic nickel processing.

Plating. The current efficiency of plating from nickel nitrate solutions was well below $5 \%$, with only $2.2 \mathrm{mg}$ of weight increase in the nickel cathode. The current efficiency decreased continuously during the plating run. As shown in Fig. 2.13, the plating is very non-uniform, spotty, friable, and very thin.

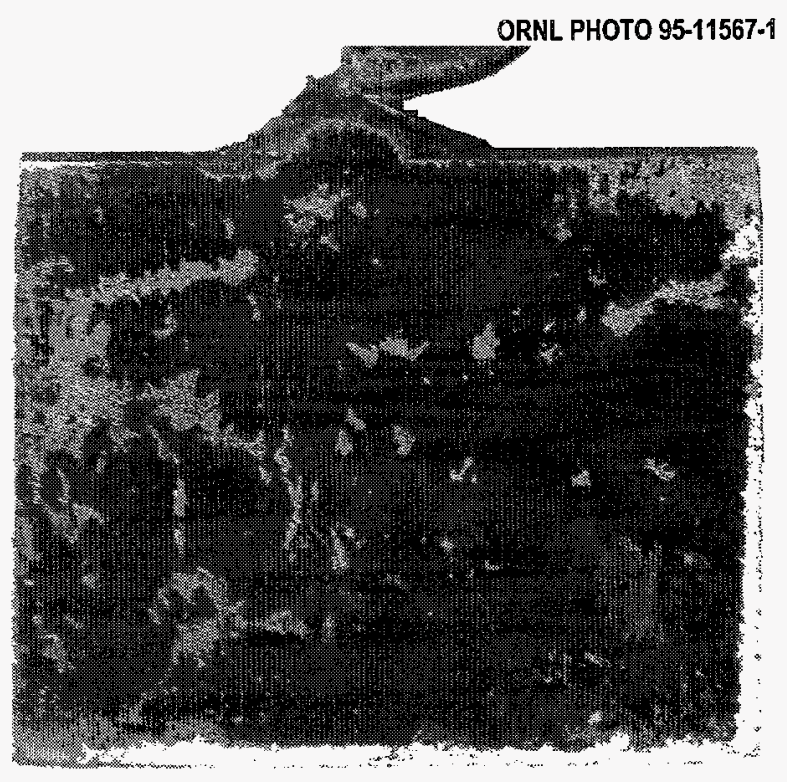

Fig. 2.13. Nickel plate from $1 M$ nickel nitrate electrolyte. 


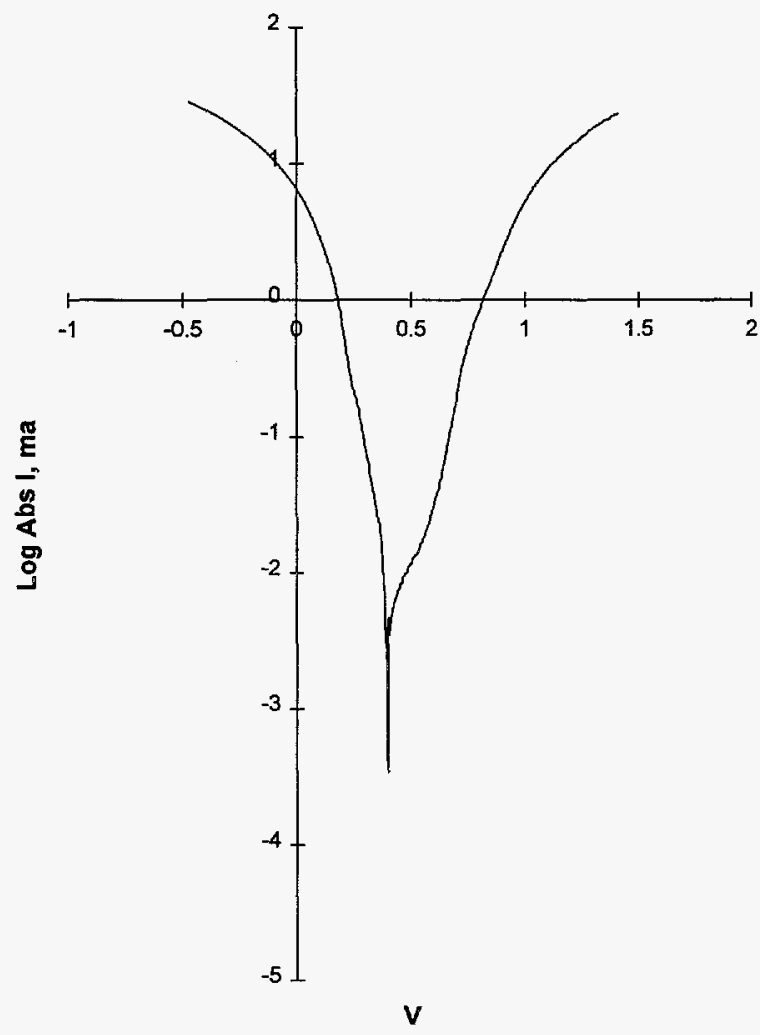

Fig. 2.14. Potentiometric scan of $1 \mathrm{M}$ nickel chloride - $0.5 M$ ammonium thiocyanate electrolyte.

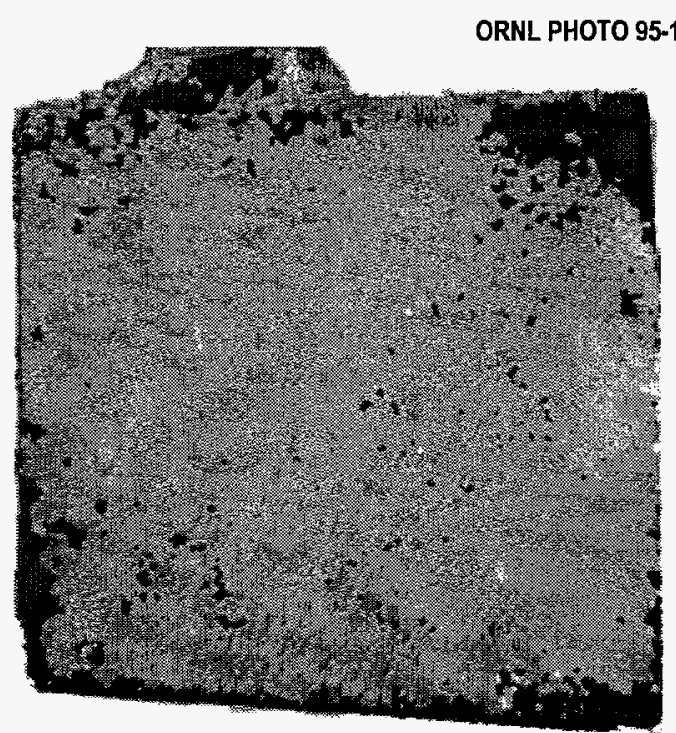

Fig. 2.15. Plate from $1 M$ nickel chloride - 0.5 $M$ ammonium thiocyanate electrolyte.

\section{$1 M$ Nickel chloride with $0.5 M$ ammonium thiocyanate}

Potentiometric scans. However, data on thiocyanate electrolytes is limited. The composite curve for a nickel chloride electrolyte with ammonium thiocyanate is shown in Fig. 2.14. The curve is relatively smooth, indicating no significant competing reactions. The potential/current curve is very similar to that of the traditional buffered nickel sulfate with sodium chloride with very similar voltage and current values.

Plating. The presence of ammonium thiocyanate increases the current efficiency to $95 \%$ as compared to the $72-81 \%$ obtained with nickel chloride solutions, although some cathode bubbles were observed. As shown in Fig. 2.15, nickel plated relatively evenly, but with poor adherence.

\section{$1 M$ Nickel chloride with $0.5 M$ ammonium chloride}

Potentiometric scans. As a control for the chloride electrolyte with ammonium thiocyanate, a $1 M$ nickel chloride electrolyte with $0.5 \mathrm{M}$ ammonium chloride was tested. The composite curve for this system, shown in Fig. 2.16, is, like that of the chloride electrolyte with thiocyanate, smooth and without indication of competing reactions.

Plating. The current efficiency of the nickel chloride electrolyte was increased by the addition of ammonium chloride to $92.9 \%$. This compared favorably with the $72-81 \%$ of $1 M$ nickel chloride. As shown in Fig. 2.17, this solution provided a clearly smooth and adherent nickel plate.

\section{Current efficiency}

Current efficiencies for the electrolytes tested are shown in Table 2.1. The conventional electrolyte, buffered nickel sulfate with sodium chloride, and the chloride electrolytes which ammonium salts had current efficiencies higher than $90 \%$. Current efficiencies for neat 


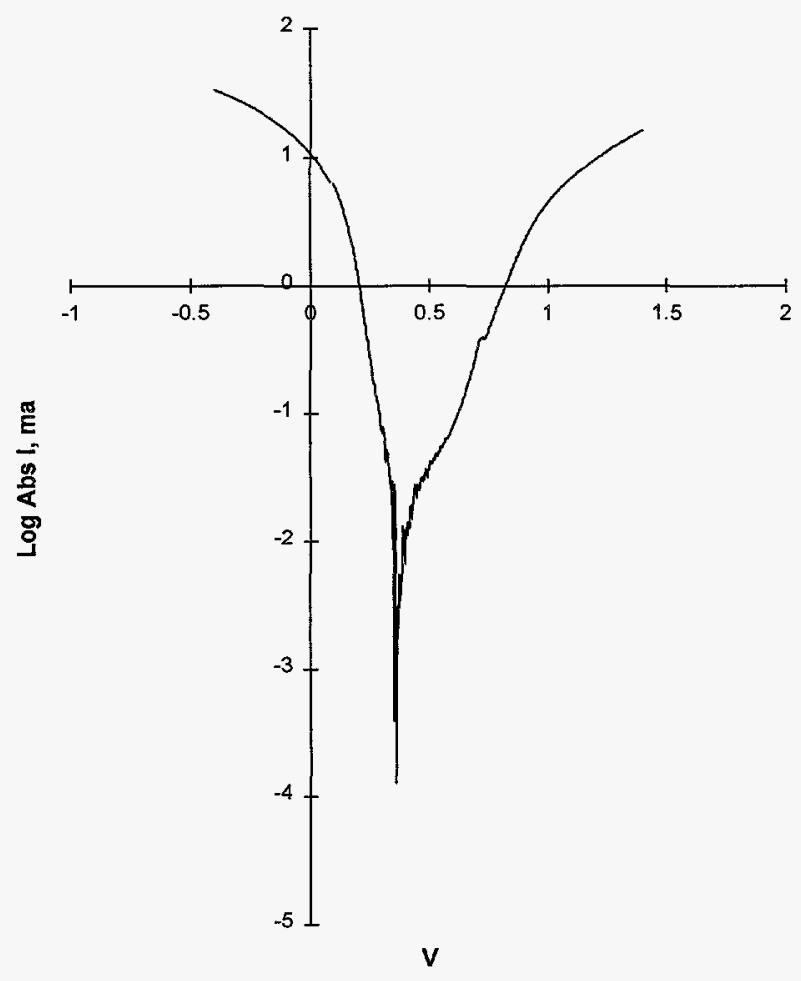

Fig. 2.16. Potentiometric scan from $1 M$ nickel chloride - 0.5 $M$ ammonium chloride electrolyte.

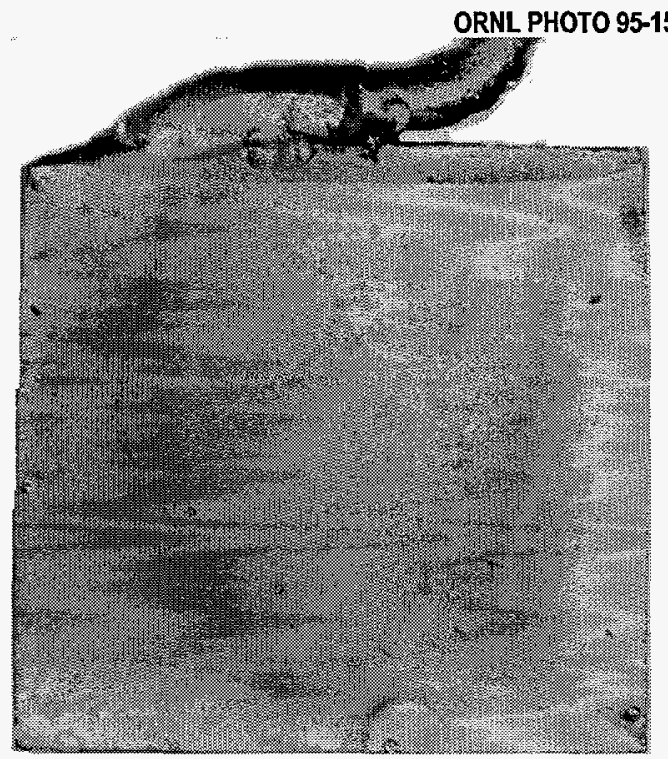

Fig. 2.17. Plate from $1 M$ nickel chloride $-0.5 M$ ammonium chloride electrolyte.

nickel chloride electrolyte were somewhat lower, probably due to blinding of the plate surface by bubbles. A nickel sulfate electrolyte with ammonium thiocyanate also performed acceptably, although the formation of crystals during cell operation indicated that the solution was supersaturated at $25 \mathrm{C}$. Although current efficiency is not the controlling factor in plant operating cost, it is probable that any of these systems could be optimized to achieve acceptable performance.

Table 2.1. Current efficiencies from microcell plating tests

\begin{tabular}{|c|c|c|c|}
\hline Composition & Coulombs & $\begin{array}{l}\text { Current } \\
\text { efficiency }\end{array}$ & Remarks \\
\hline$\underset{\mathrm{H}_{3} \mathrm{BO}_{4}}{\mathrm{M} \mathrm{NiSO}_{4}}+0.5 \mathrm{M} \mathrm{NaCl}+$ & 200 & 95.6 & $\begin{array}{l}\text { Run at high current corresponding to total plate } \\
\text { area. }\end{array}$ \\
\hline $\begin{array}{l}1 \mathrm{M} \mathrm{NiSO}_{4}+0.5 \mathrm{M} \mathrm{NaCl}+ \\
\mathrm{H}_{3} \mathrm{BO}_{4}\end{array}$ & 206 & 94.3 & $\begin{array}{l}\text { Run at low current, } 17 \mathrm{~mA} / \mathrm{cm}^{2} \text { to correspond to } \\
\text { single surface of plate. }\end{array}$ \\
\hline$\underset{\mathrm{H}_{3} \mathrm{BO}_{4}}{\mathrm{MiSO}_{4}}+1.5 \mathrm{M} \mathrm{NaCl}+$ & 200 & 99.8 & Ran really well. \\
\hline $1 \mathrm{M} \mathrm{NiCl}_{2}$ & 285 & 81.3 & Current increased to $38 \mathrm{~mA} / \mathrm{cm}^{2}$ during run. \\
\hline $1 \mathrm{M} \mathrm{NiCl}_{2}$ & 184 & 71.6 & $\begin{array}{l}\text { Current controlled to }<20 \mathrm{~mA} \mathrm{~cm}^{2} \text {. Gas formation } \\
\text { observed. }\end{array}$ \\
\hline $4 \mathrm{M} \mathrm{NiCl}_{2}$ & 202 & 98.0 & Upper limit of solubility below $5 \mathrm{M}$ at $25 \mathrm{C}$. \\
\hline $1 \mathrm{M} \mathrm{Ni}\left(\mathrm{NO}_{3}\right)_{2}$ & 169 & Low & $\begin{array}{l}\text { Current decreased to } 6 \mathrm{~mA} / \mathrm{cm}^{2} \text { during run. Only } \\
2.2 \mathrm{mg} \text { material plated. Analysis indicates nitrite } \\
\text { formation. }\end{array}$ \\
\hline $1 \mathrm{M} \mathrm{NiCl}_{2}+0.5 \mathrm{M} \mathrm{NH}_{4} \mathrm{SCN}$ & 209 & 95.0 & $\begin{array}{l}\text { Some cathode bubbles. Plate partially detached } \\
\text { during drying. }\end{array}$ \\
\hline $1 \mathrm{M} \mathrm{NiCl}_{2}+0.5 \mathrm{M} \mathrm{NH}_{4} \mathrm{Cl}$ & 200 & 92.9 & \\
\hline $1 \mathrm{M} \mathrm{NiSO}_{4}+0.5 \mathrm{M} \mathrm{NH}_{4} \mathrm{SCN}$ & 197 & 75.9 & Suspersaturated; crystals formed in cell at $25 \mathrm{C}$. \\
\hline
\end{tabular}


Neat nickel nitrate does not appear to be an acceptable electrolyte. During operation of the microcell, current decreased continuously, reaching a low of $6 \mathrm{~mA} / \mathrm{cm}^{2}$. As noted earlier, polarization studies reproducibly indicated that nickel deposition was not the controlling reaction in the system. Analysis of the electrolyte indicated that nitrate was being reduced to nitrite during cell operations. 


\section{Contaminant Removal}

Present industrial technologies have been developed to recover nickel and other metal products from ores and concentrates which contain less than $50 \%$ nickel. Separations processes have been developed to sequentially remove high volume contaminants, such as cobalt and iron, as saleable products.

Purification of the nickel electrolyte stream to meet de minimus standards presents a different challenge because the separations needs are both very exacting and very different in nature from the requirements of conventional processes. Scrap nickel available from first generation diffusion plants typically meets or exceeds commercial standards for overall purity. As shown in Table 3.1, radiological contaminants in the ingots likely to be processed first are low. Both $U$ and Tc contents are in the ppm range; other contaminants are in or below the ppb range. Based on these analyses, the actual weights of these contaminants are small:

$14.8 \mathrm{~kg} \mathrm{U}$, average enrichment $0.925 \%{ }^{235} \mathrm{U} ; 7.2 \mathrm{~kg}{ }^{99} \mathrm{Tc} ; 4.8 \mathrm{~g}{ }^{237} \mathrm{~Np}$, and $<43 \mathrm{mg}{ }^{239} \mathrm{Pu}$.

Table 3.2 indicates the levels of contaminants required for export of purified nickel. These levels of purity could be met by a series of solvent extraction, ion exchange, or, in some cases, precipitation or filtration steps directed at removing each individual contaminant. There are other options. For example, countercurrent solvent extraction cascades, which have long been used for purification of uranium and other radiological species, could potentially

Table 3.1. Radiological aaniyses of 30 individual Paducah nickel ingots

\begin{tabular}{|c|c|c|c|c|c|c|}
\hline Plant & Button & $\begin{array}{c}{ }^{237} \mathrm{~Np}, \\
\mathrm{ppb}\end{array}$ & $\begin{array}{c}\text { 239Pu, } \\
\text { ppb }\end{array}$ & $\begin{array}{l}\text { 99-Tc, } \\
\text { ppm }\end{array}$ & $\begin{array}{c}\text { U, } \\
\text { ppm }\end{array}$ & $\% 235 \mathrm{U}$ \\
\hline G & 110,111 & $<0.5$ & $<0.005$ & 0.69 & 1.2 & 1.15 \\
\hline G & 127 & $<0.5$ & $<0.005$ & 0.56 & 1.9 & 1.05 \\
\hline G & 131 & $<0.5$ & $<0.005$ & 0.75 & 1.4 & 0.95 \\
\hline$G$ & 203 & $<0.5$ & $<0.005$ & 0.73 & 1.3 & 1.36 \\
\hline$G$ & 208,209 & $<0.5$ & $<0.005$ & 0.82 & 1.5 & 1.2 \\
\hline$G$ & 212,213 & $<0.5$ & $<0.005$ & 0.72 & 0.6 & 1.22 \\
\hline$G$ & 254 & $<0.5$ & $<0.005$ & 0.79 & 1.3 & 1.27 \\
\hline G & 286 & $<0.5$ & $<0.005$ & 0.91 & 2.3 & 1.28 \\
\hline G & 292 & $<0.5$ & $<0.005$ & 0.96 & 0.3 & 1.13 \\
\hline$G$ & 295 & $<0.5$ & $<0.005$ & 1.07 & 0.6 & 1.15 \\
\hline$P$ & 750 & $<0.5$ & $<0.005$ & 0.53 & 2.8 & 0.61 \\
\hline$P$ & 885 & 0.6 & 0.005 & 0.69 & 12.6 & 0.6 \\
\hline $\mathbf{P}$ & 1234 & 0.8 & $<0.005$ & 0.41 & 2.4 & 0.67 \\
\hline$P$ & 1424 & $<0.5$ & $<0.005$ & 1.3 & 3.2 & 0.67 \\
\hline$P$ & 1680 & $<0.9$ & $<0.005$ & 1.88 & 2.4 & 0.57 \\
\hline$P$ & 1889 & 0.6 & $<0.005$ & 1.05 & 0.9 & 0.68 \\
\hline$P$ & 2268 & $<0.5$ & $<0.005$ & 2.13 & 1.4 & 0.64 \\
\hline$P$ & 2503 & $<1.2$ & $<0.005$ & 2 & 1.6 & 0.67 \\
\hline$P$ & 2695 & $<0.5$ & $<0.005$ & 0.98 & 1.5 & 0.66 \\
\hline$P$ & 3128 & 0.9 & $<0.005$ & 4.21 & 3.3 & 0.86 \\
\hline OR & 886 & $<0.5$ & $<0.005$ & 0.22 & 0.7 & 1.06 \\
\hline OR & 1148 & $<0.5$ & $<0.005$ & 0.26 & 1.2 & 0.75 \\
\hline OR & 1711 & $<0.5$ & $<0.005$ & 0.19 & 0.6 & 0.84 \\
\hline OR & 1891 & $<0.5$ & $<0.005$ & 0.26 & 0.9 & 0.72 \\
\hline OR & 2144 & $<0.5$ & $<0.005$ & 0.24 & 0.2 & 1.01 \\
\hline OR & 2164 & $<0.5$ & $<0.005$ & 0.51 & 1 & 0.95 \\
\hline OR & 2574 & $<0.5$ & $<0.005$ & 0.19 & 1.1 & 0.9 \\
\hline OR & 2821 & $<0.5$ & $<0.005$ & 0.19 & 1.3 & 1.04 \\
\hline OR & 3025 & $<0.5$ & $<0.005$ & 0.16 & 0.2 & 1.12 \\
\hline OR & 3488 & $<0.5$ & $<0.005$ & 0.12 & 0.6 & 0.98 \\
\hline
\end{tabular}

Source: Science Applications Intemational Corporation 1995.

${ }^{a} G=$ General Atomic; $P$ Paducah; $O=O R G D P$ 
Table 3.2. Regulatory requirements for export:a

\begin{tabular}{ll}
\hline Item & Requirement \\
\hline Low enriched uranium & $17.5 \mathrm{ppm}$ \\
Plutonium & $<1 \mathrm{~g}$ per shipment, $100 \mathrm{~g}$ or less \\
& per country per year $(<10 \mathrm{~Bq} / \mathrm{g})$ \\
Neptunium & $<0.1 \mathrm{~Bq} / \mathrm{g}$ \\
Other byproduct & to keep radiation (primarily \\
material & technetium) $<20 \mathrm{~Bq} / \mathrm{g}$ \\
\hline
\end{tabular}

a Standards for domestic reuse not yet established be optimized to provide the potential for a multi-contaminant system. This is opposite in conception to current radiological separations processes, which are typically optimized to provide separation and purification of a single chemical species. Materials properties are also a major concern. Radiological separations are typically low-volume due to criticality concerns and may have been developed with little concern for compatibility with downstream

process equipment. For example, dibutyl carbitol provides good uranium separations but is incompatible with materials, such as plastics, likely to be used in modern process equipment.

The project goal is to optimize or reoptimize industrially-proven separations technologies to provide effective stripping of radiological contaminants while minimizing incompatibilities with downstream electrolytic equipment and processes. Minimization of process waste is also a goal. Understanding and evaluation of the factors critical to optimization of separations will be developed as the project matures. At this time, however, the main process questions involve defining a series of possible extractants and determining whether they do, in fact, separate expected contaminants, such as technetium, uranium, or cobalt, from high-nickel electrolytes which simulate expected process streams. Because of the very low levels of contaminants, the feasibility of using ion exchange, either for contaminant removal or for polishing, will also be evaluated.

\section{Industrial process extractants}

A variety of solvent extraction processes, as shown in Table 3.3, have been developed for industrial-scale metal separations. These range from relatively complicated processes, such a those developed for sequentially fractionating the metals recovered from ocean floor nodules, to simpler separations of the constituents of spent catalysts.

Sefton, Fox, and Lorenz (1989) disclosed a process for the separation of the metals, aluminum, cobalt, molybdenum, nickel, tungsten, and vanadium found in conventional

Table 3.3. Parameters for extractive separations of base metals

\begin{tabular}{|c|c|c|c|c|c|}
\hline Extractant & Diluent & Separation ${ }^{b}$ & Solution & Source & Remarks \\
\hline \multirow[t]{2}{*}{ Di-2EHPA, $15 \%$} & \multirow[t]{2}{*}{ ESCAID 100} & Co from $\mathrm{Ni}$ & \multirow{2}{*}{$\begin{array}{c}\mathrm{pH}=5.9 \text { With } \\
\text { ammonia }\end{array}$} & \multirow[t]{2}{*}{ Bouboulis } & \\
\hline & & $K_{s}=33$ & & & \\
\hline ADOGEN 381, 3.6\% & SOLVESSO 150 & Co from $\mathrm{Ni}$ & $6 \mathrm{NHCl}$ & Bouboulis & \\
\hline \multirow[t]{3}{*}{ TIOA, 15\% } & \multirow[t]{3}{*}{ Aomatic solvent } & Co from $\mathrm{Ni}$ & $250 \mathrm{~g} / \mathrm{Cl}$ & \multirow{3}{*}{$\begin{array}{l}\text { Stensholt et al } \\
1986\end{array}$} & \multirow{3}{*}{$\begin{array}{l}80-90 \mathrm{~g} / \mathrm{Co} \text { in final } \\
\text { backwash }\end{array}$} \\
\hline & & \multicolumn{2}{|l|}{$\begin{array}{l}\text { Extractant used at } \\
5.5 \mathrm{~g} / \mathrm{l} \text { of } \\
\text { electrolyte. }\end{array}$} & & \\
\hline & & \multicolumn{2}{|l|}{$\begin{array}{l}\text { 4-stage } K_{d}=10,000 \\
\text { using mixer- } \\
\text { settlers }\end{array}$} & & \\
\hline
\end{tabular}

${ }^{2} A D O G E N 381=$ triisooctylamine; Di-2EHPA = di(2-ethylhexyl)phosphoric acid; ESCAID $100=20 \%$ aromatic low viscosity hydrocarbon diluent; SOLVESSO $150=100 \%$ aromatic diluent ; TIOA = triisooctylamine. ${ }^{b} \mathrm{~K}_{d}=$ distribution coefficient, org/aq; $\mathrm{K}_{s}=$ separation factor. 
refinery catalysts. A variety of process configurations were presented. Most have several common steps. First, the spent hydrodesulfurization catalyst was dissolved in hydrochloric acid acid to remove cobalt, vanadium, nickel, and aluminum. To remove the molybedenum, leach residues were then calcined and dissolved in acid. Silica was removed from the second leach solution as a solid. Molybdenum was then precipitated as the sulfide. They also found that, at $\mathrm{pH}$ values between 1 and 2.5 , both nickel and cobalt could be precipitated as sulfides by addition of sodium or hydrogen sulfides. The low $\mathrm{pH}$ prevented coprecipitation of aluminum. In variations of the proposed process schemes, precipitation was replaced with solvent extraction. For example, vanadium could be removed by trioctylphosphine oxide extraction; nickel and cobalt, by trioctylamine; and iron, by tributylphosphate.

Ritcey (1969) of the Canadian Department of Energy, Mines, and Resources reviewed industrial-scale use of solvent extraction systems in base metal purification processes. $\mathrm{He}$ reported use of commercial solvent extraction systems for separation of uranium from vanadium, cobalt from nickel, niobium from tantalum, zirconium from hafnium, and for the purification of copper, uranium, thorium, and the rare earths. Commonly used extractants included quarternatry and tertiary amines, tributyl phosphate, alkylphosphoric acids, carboxylic acids, slcohols, ketones, and metallic soaps. Extraction from hydrochloric acid solutions was typically more effective than from nitric acid solutions. Across a number of industrial metal purification operations, solvent extraction processes were regarded as low in cost and operating requirements and high in yield and specificity. They were judged particularly effective in removing low concentrations of metal from contaminated leach solutions.

Bouboulis (1979) evaluated the effect of diluent composition on separation of cobalt and nickel by di(2-ethylhexyl)phosphoric acid, tertiary amines, and a quarternary ammonium salt. With di(2-ethylhexyl)phosphoric acid, the extraction of cobalt vs. nickel increases with increasing aromatics and decreasing $\mathrm{pH}$. The addition of a $5 \%$ tributyl phosphate to decrease the formation of a third phase resulted in a decrease of roughly an order of magnitude in the cobalt/nickel separation factor. Extraction of cobalt from $6 \mathrm{~N} \mathrm{HCl}$ by $3.6 \%$ triisooctylamine as functions of diluent aromatic contents and suppressors of third phase formation were also evaluated. Generally, third phase formation (and the need for suppressors) decreased with increasing aromatic content, while extraction of cobalt increased. Settling time increased slightly with decreasing aromatic concentration and increasing addition of third-phase suppressors. Cobalt/nickel separation factors for the $3.6 \%$ triisooctylamine systemwere roughly 1-1/2 times as high as those for di(2-ethylhexyl)phosphoric acid. Trends for a related quarternary amine extractant, ALIQUAT 336 were qualitatively similar, although lower amounts of third phase suppressor and longer phase separation times were required. Isodecanol was found to be a more effective third phase suppressor than tributylphosphate.

Solvent extraction is only beginning to find use in nickel electrorefining and electrowinning operations. Stensholt and coworkers $(1986 \mathrm{a}, 1986 \mathrm{~b}, 1988)$ have described the operations of the Falconbridge refinery at Kristiansaand, Norway. This refinery uses solvent extraction of high-chloride nickel electrolyte to remove and recover cobalt. The extractant, $5 \%$ triisooctylamine in an aromatic diluent, is used at a very low ratio $-5.5 \mathrm{~g} / \mathrm{l}$ of electrolyte - and backwashed with a combination of spent cobalt anolyte and water to give a $80-90$ 
g/ cobalt electrolyte. The use of the chloride process, with its advanced separations, has increased capacity and decreased costs. Published reports do not indicate any major increases in waste discharge or any unresolved materials incompatibilities. It may also be possible to improve on the performance of the Falconbridge system.

Logeat, Mankowski, Molinier, and Lenzi (1982) evaluated conditions for extractive separation of copper from cobalt by $0.3 \mathrm{~N}$ triisooctylamine diluted with Solvesso 100 . By varying the chloride concentration of the raffinate and stripping solutions, they were able to effect nearly complete separation of cobalt from copper at yields of both metals approaching $100 \%$. A high agitation rate was required for high extraction yield. Logeat and coworkers indicate that their optimization could improve on that of the Falconbridge plant by several-fold.

Some nickel streams may contain other radiological species, such as ${ }^{60} \mathrm{Co}$, for which complexation and extraction (Griffith, Jasny and Tupper 1952) have been shown to be effective. However, radiological separations have historically utilized extreme $\mathrm{pH}$ or high salt concentrations, rather than complexation, to improve transfer into solvent

\section{Technetium and actinide extractions}

Uranium and transuranic extractants have been developed for three primary purposes: concentration of uranium from ores, purification of different actinide species for analysis, and reprocessing of uranium or plutonium. These separations require a high degree of specificity, or separations factor, for a given metal or class of metals.

Müller reviewed the extraction of actinide species from salt solutions by alkyl-substituted ammonium salts (1967). Although variation can be considerable, several trends emerged from the studies reviewed. These are shown in Table 3.4. Müller indicated that all of the alkyl amines readily formsalts in the presence of acid salt solutions. Only small amounts of acid, relative to salt, were required for salt formation or effective extraction. However, when acid alone was used as the aqueous phase, the highest distribution coefficients occurred around $6 M$ for monovalent acids and decreased at higher acid concentrations. Most metals, including actinides, were extracted by trialkyl ammonium salts, although there is considerable variation in extractability with metal valence. Most of the common mineral acids, or their simple salts, formed aqueous phases permitting effective extraction of actinides by the range of alkyl amines. Formation of a third, or middle, phase, was a major concern in many systems. From an engineering viewpoint, the abilities of trialkyl amines and trialkyl ammonium salts to extract a broad range of metals at a

Table 3.4. Trends in actinide extraction by alkyl ammonium salts

\begin{tabular}{|c|c|}
\hline Trend & Observation \\
\hline Extraction by amines: & Teritary > secondary > primary \\
\hline Solubility in aqueous & Short chain > long chain \\
\hline \multirow[t]{2}{*}{ Extraction of mineral acids } & $\mathrm{HI}>\mathrm{HBr}>\mathrm{HCl}$ \\
\hline & Cyclohexane > chloroform \\
\hline Normal acid : amine ratio & 2 Best for most systems \\
\hline Third phase formation & Suppressed by higher alcohols \\
\hline Complexing agents formed by acids & $\begin{array}{l}\text { Acetic, citric, ethylenediamine } \\
\text { tetraacetic, hydroxybutyric, oxadic, } \\
\text { and tartaric }\end{array}$ \\
\hline Extractability of tetravalent actinides & $\mathrm{Pu}>\mathrm{Np}>\mathrm{U}>\mathrm{Th}$ \\
\hline Extractability of hexavalent actinides & $\mathrm{Pu}, \mathrm{Np}>\mathrm{U}$ \\
\hline Relative extractrability in nitrate & $\begin{array}{l}\text { Tetravalent actinides }>\text { hexavalent } \\
\text { actinides }\end{array}$ \\
\hline Relative extractability in chloride & Hexavalent $>$ tetravalent \\
\hline Uranium extractability by electrolyte & Chloride $>$ nitrate $>$ sulfate \\
\hline
\end{tabular}


number of different valence states is interesting because it could permit optimization of a single extraction to strip several radiological contaminants in a single step. A summary of effective extraction conditions reported by several groups of researchers is presented in Table 3.5.

Table 3.5. Solvent extraction of technetium and uranium from acid solutions

\begin{tabular}{|c|c|c|c|c|c|}
\hline Extractant & Diluent & Separation & Solution & Source & Remarks \\
\hline TIOA, $2.5-5 \%$ & $\begin{array}{l}3 \% \text { Decanol in } \\
\text { kerosene }\end{array}$ & $\begin{array}{l}U \text { from lignite } \\
\text { Est. } K_{d}, v / v-10\end{array}$ & $\begin{array}{c}40 \% \text { w+v } \mathrm{Fe}_{2}\left(\mathrm{SO}_{4}\right)_{3} \\
\cdot \mathrm{H}_{2} \mathrm{O}+0.75 \% \\
\mathrm{H}_{2} \mathrm{SO}_{4}, \mathrm{pH}<0\end{array}$ & Schultze et al 1981 & $\begin{array}{l}\text { Sulfate competed for } \\
\text { extractant.. } \\
\left(\mathrm{NH}_{4}\right)_{2} \mathrm{SO}_{4} \\
\text { backwash. }\end{array}$ \\
\hline $\begin{array}{c}\text { TIOA, 3\% with } \\
\text { TOPO, } 3 \%\end{array}$ & Kerosene & $\begin{array}{l}\text { U from acid leach } \\
\text { solution. } \\
\text { Est. } K_{d}, v / v \sim 135\end{array}$ & $\begin{array}{l}0.1 \% \mathrm{U}_{3} \mathrm{O}_{8}, 50 \mathrm{~g} / \mathrm{l} \\
\mathrm{SO}_{4}=\text { of which } 10 \\
\mathrm{~g} \text { was free } \mathrm{H}_{2} \mathrm{SO}_{4}\end{array}$ & $\begin{array}{l}\text { Itzkovitch and } \\
\text { Rickelton 1982, } 3\end{array}$ & $\begin{array}{l}\text { Bachwash into } \\
\mathrm{Na}_{2} \mathrm{CO}_{3} .\end{array}$ \\
\hline TCAS, $25 \%$ & Kerosene & $\begin{array}{l}\text { U from acid ore } \\
\text { leach in the } \\
\text { presence of ore }\end{array}$ & $\begin{array}{l}\mathrm{H}_{2} \mathrm{SO}_{4} \text { acid leach } \\
\text { with } 34 \% \text { ore } \\
\text { solids slurry, } \mathrm{pH}= \\
1.5\end{array}$ & Boutin et al 1967 & $\begin{array}{c}\text { Also extracted } \mathrm{Be} \text {, } \\
\mathrm{Co}, \mathrm{Zr} \text {, and } \mathrm{Mo}\end{array}$ \\
\hline Cyclohexanone & None & $\begin{array}{l}\text { Tc from } R u \\
K_{d}=82-199\end{array}$ & $0.2-4 \mathrm{NH}_{2} \mathrm{SO}_{4}$ & $\begin{array}{l}\text { Qing-Jiang et al } \\
1989\end{array}$ & $\begin{array}{l}\text { Back wash into } \\
\text { water removes } 43- \\
97 \%\end{array}$ \\
\hline TIOA, 5\% & Xylene & $\begin{array}{l}\text { Tc from Ru } \\
K_{d}=636-4667\end{array}$ & $0.2-4 \mathrm{~N} \mathrm{H}_{2} \mathrm{SO}_{4}$ & $\begin{array}{l}\text { Qing-Jiang et al } \\
1989\end{array}$ & $\begin{array}{l}\text { Back wash into } 2 \mathrm{~N} \\
\mathrm{NaOH} \text { removes } \\
99.9 \%\end{array}$ \\
\hline TOA, $16.7 \%$ & $\begin{array}{l}\text { Styrene- } \\
\text { divinylbenzene } \\
\text { copolymer }\end{array}$ & $\begin{array}{l}U \text { from mineral acids } \\
K_{d}=2-200\end{array}$ & $1-10 \mathrm{M} \mathrm{HNO}_{3}$ & $\begin{array}{l}\text { Beranova and } \\
\text { Tejecky } 1971\end{array}$ & $\begin{array}{l}\text { U/Ru separation } \\
\text { factor } \sim 15 \text { at } 7.6 \\
\mathrm{M} \mathrm{HNO} 3\end{array}$ \\
\hline
\end{tabular}

TCAS = tricapryl aminesulphate; $T$ IOA = trisooctylamine; $T O A=$ trioctylamine.

The Bureau of Mines developed processes for the extraction of uranium from lignite and other carbonaceous ores (Schultze, Bauer, and Morimoto 1981). Most promising was the dissolution of uranium into a solution which contained $200 \mathrm{~g}$ of ferric sulfate hydrate in $500 \mathrm{ml}$ of water to which $3 \mathrm{ml}$ of concentrated sulfuric acid was added. Finely ground lignite was contacted with this solution for several hours. Uranium was then extracted by contacting the ferric sulfate solution with 2.5 to $5 \%$ triisooctylamine in kerosene with $5 \%$ decanol. The uranium was removed by backwashing with an ammonium sulfate solution whose final $\mathrm{pH}$ was adjusted to $2.5-2.9$.

Itzkovitch and Rickelton $(1982,1983)$ described extraction of uranium from acid leach solution with a combinaton of $2-5 \%$ aliphatic amine (or its sodium salts) and $2-5 \%$ trialkylphosphine oxides dispersed in water-immiscible aromatic or aliphatic hydrocarbons. Several different aliphatic amines, n-octylamine, 2-ethylhexylamine, $\mathrm{n}$-dodecylamine, $\mathrm{n}$ octadecylamine, di-n-octylamine, bis-(2-ethylhexylamine), di-n-octadecylmaine, tris(2ethylhexyl)amine, triisooctylamine, and tri-n-deodecylamine were all found to be satisfactory extractants. The acid uranium leach solution contained at leat $50 \mathrm{~g} / \mathrm{total}$

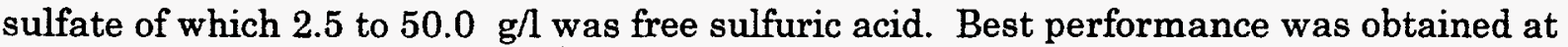
free sulfuric acid values between 2.5 and $20 \mathrm{~g} / \mathrm{l}$. Uranium was backwashed into sodium carbonate solution.

Boutin and Malvanin (1967) report successful extraction of uranium from ore slurries suspended in acid leach solution. A countercurrent system in which the ore slurry flowed down while the kerosene - extractant phase flowed up. The authors resport that, using a 
50 foot column, removal efficiencies of $>99.9 \%$ could be achieved with a loss of less than $0.02 \mathrm{gal}$ of amine per ton of solids treated. They also note that similar systems can be used to separate a variety of metals. For example, triisooctylamine can be used to separate beryllium, vanadium, zirconium, and molybdenum from sulfuric acid solution.

Vieux and Rutagengwa (1975) determined equilibrium constants for formation of U(VI) complexes with tri-isooctylammonium sulfate $(1.45 \pm 0.58) \times 10^{-23}$ and triisooctylammonium chloride $(4.80 \pm 0.53) \times 10^{-13}$. in $o$-dichlorobenzene. The equilibrium constants for formation of both sulfate $\left(8.22 \times 10^{-9}\right)$ and chloride $\left(1.05 \pm 0.03 \times 10^{-5}\right)$ triisooctylammonium salts indicate that they are readily formed in acid media.

Qing-Jiang and coworkers (1989) developed extraction procedues which permitted the separation and recovery of technetium and ruthenium from environmental samples contaminated by the Chernobyl accident. Although both metals are tyoically recovered in conventional analytical methods, these researchers found that a combination of careful selection of extraction conditions and control of metal valence state permitted near quantitative separation and recovery. The $\mathrm{TcO}_{4}$ ion is readily extracted from 2 $\mathrm{N} \mathrm{H}_{2} \mathrm{SO}_{4}$ solution into $5 \%$ TIOA in xylene. Backwash into $2 \mathrm{~N} \mathrm{NaOH}$ is nearly quantitative. Although this procedure was developed for analytical separations, the control of oxidation state and the extraction conditions themselves may be useful in setting parameters for industrial separations.

Wu and Lo (1990) evaluated use of tertiary amines diluted into xylene for the separation of uranium from its daughter products. They evaluated extraction of uranium, plutonium, and americium from nitric and hydrochloric acids. Efficiency of uranium and plutonium extraction from hydrochloric acid reached a maximum of approximately $80 \%$ around or above $6 M$. In nitric acid, extraction efficiency remained relatively constant to approximately $10 \mathrm{M}$; in hydrochloric acid, it gradually decreases. Although extraction efficiencies of uranium and plutonium follow a reasonably similar pattern, Wu and Lo were able to define conditions, $8 \mathrm{M} \mathrm{HCl}$ aqueous extracted with $10 \%$ trilaurylamine in xylene, which favored the extraction of uranium over its daughters.

Sundaramurthi and Shinde (1991) evaluated extraction and separation of uranium and lead with anion exchangers. After extraction, uranium and lead were back washed into an aqueous solution for spectrophotometric analysis. Nearly $100 \%$ of the uranium was rapidly extracted from $0.05 \mathrm{M}$ salicylate into any of the liquid anion exchangers diluted in xylene at $\mathrm{pH}$ values below 4. Only Aliquat 336 (tricaprylmethylammonium chloride) gave effective extraction at $\mathrm{pH}$ values up to 7 . Similarly, lead was extracted nearly quantitatively from $0.025 \mathrm{M}$ salicylate into $1 \%$ Aliquat 336 in xylene at $\mathrm{pH}$ values between 4 and 8. The other exchangers tested, Amberlite LA-1 and LA-2, triocylamine, and triisooctylamine, had narrower effective $\mathrm{pH}$ ranges. Use of diluents other than xylene and toluene for Aliquat 336 yielded lower uranium and lead extraction efficiencies. Considerations of distribution ratio data indicated that the disalicylate complexes of both uranium and lead were the species extracted. Through the use of selective backwashing, uranium and lead could be separated from a variety of other metallic species, including thorium, titanium, zirconium, vanadium, firon, chromium, copper, and cobalt. The extraction was quantitative for a variety of leaded alloys, spiked animal bone and mill, and for lead in air samples.

The use of a concentrated simple salt electrolyte, such as the Falconbridge chloride dissolution system, could also permit the use of ion exchange or reverse phase 
chromatographic separations. Beranova and Teinecky (1972) discuss the use of teriatry amines immobilized on conventional styrene-divinylbenzene copolymers. As shown in Table 3.5, these materials gave excellent separation of uranium at high chloride concentrations. Separation of ruthenium, which is similar to technetium was, however, poor.

\section{Ion exchange separations}

The 6 to $8 M$ acidic chloride solutions projected from the Falconbridge process make the use of quaternary ammonium anion exchangers, such as Dowex-1, a potentially attractive alternative for removal of impurities. The feed would be primarily $\mathrm{NiCl}_{2}$, and the contaminants are virtually at trace levels, about $10^{-5} \mathrm{M}$ being the highest from the list in Table 3.1. Kraus and Nelson (1955) systematically studied the adsorption of most of the periodic table on Dowex-1 (usually X-10) as a function of $\mathrm{HCl}$ solution. $\mathrm{Ni}(\mathrm{II})$ was essentially not adsorbed at $6 \mathrm{M} \mathrm{HCl}$, whereas distribution coefficients (L/Kg) of Tc(VII) and $\mathrm{U}(\mathrm{VI})$ exceed 100. Adsorptions of $\mathrm{Np}(\mathrm{VI})$ and $\mathrm{Pu}(\mathrm{VI})$ were lower (Kraus, Phillips, and Nelson (1962)) and of these elements in the (IV) valence state, even lower. However, distribution coefficients from salt solutions ( $\left.\mathrm{LiCl}, \mathrm{CaCl}_{2}, \mathrm{MgCl}_{2}, \mathrm{AlCl}_{3}\right)$ of the same chloride concentration were found to be sometimes a hundred times greater (Kraus, et al, 1955; . Kraus and Nelson 1958). Diamond and Whitney (1966) discussed this "acid effect" in detail. This implies that, with the exception of Tc(VII, ) the contaminants expected in the nickel recycle stream could be removed from a hundred or more column volumes of electrolyte prior to regeneration. A different eluent would be required for technetium.

\section{Backwashing and stripping of radiological contaminants from extractants}

The literature indicates that technetium and actinides can be readily removed from acid solutions using either solvent extraction or ion exchange separations. Both of these technologies have been used successfully at industrial scale for similar separations. The high purity of nickel feedstock and the very low levels of radiological species suggest the possibility of concentrating these contaminants into a small waste volume. In order to do this, effective backwashing or stripping of the radiological contaminants into limited volumes will be required.

Several investigators have reported the conditions and distribution coefficients for recovery of actinides and technetium from organic amine extractants (Müller 1967, Keder 1962). These systems are characterized by an extraction curve with a strong maximum at its center and very low values, which favor extraction of the metal into the aqueous, at very low or very high acid or $\mathrm{pH}$ levels. Qing-Jiang and coworkers (1989) reported distribution coefficients of 0.0013 for technetium from $5 \%$ triisooctylamine in xylene into $2 \mathrm{~N}$ sodium hydroxide. These systems were developed primarily for use in analysis. Although they are likely to provide satisfactory performance in full-scale equipment, they should be evaluated and optimized as process scale increases.

Low contaminant levels in nickel feedstock are likely to permit processing of 100 or more ion exchange column volumes before breakthrough occurs. When the column is fully loaded with radiological contaminants, these materials will be removed into a small, concentrated volume. The data reported by Kraus and coworkers $(1955,1962,1968)$ indicate that all of the actinides can be stripped from Dowex-1 with a small volume of low concentration, perhaps $0.1 M$, hydrochloric acid. Appropriate stripping conditions for 
technetium were not considered in these reports. If appropriate data for technetium are not found, laboratory investigations to profile stripping from ion exchange resins will be undertaken.

Removal of technetium by cementation during passage of the electrolyte through a bed of nickel powder is also possible if a method for removing it from ion exchange resin is not available.

\section{Confirmation of contaminant removals}

As discussed above, there are several options for the removal of radiological contaminants from nickel scrap. Both ion exchange and solvent extraction have been practiced successfully at industrial scale; extraction with triisooctylamine is used successfully to remove cobalt from nickel chloride solutions in the Falconbridge chloride electrowinning process. However, the separations reported in the literature typically involve removal of trace contaminants from acid chloride solutions, rather than from acidic nickel chloride solutions. Separation of uranium and pertechnate from nickel electrolyte solutions was evvaluated using a series of bench tests.

The first question was whether it would be possible to remove technetium from the range of proposed electrolytes at neutral $\mathrm{pH}$. This is a concern because electrorefining processes typically operate near neutrality. However, as discussed above, solvent extractions with tertiary amines are typically conducted at low $\mathrm{pH}$ because distribution coefficients increase as $\mathrm{pH}$ decreases. As shown in Table 3.6, classic solvent extraction is somewhat successful in

Table 3.6. Distribution of pertechnate between organic and neutal aqueous phases at $25 \mathrm{C}$.

\begin{tabular}{llc}
\hline Organic & Aqueous & $\mathrm{K}_{\mathrm{d}}$, orglaq \\
\hline TIOA & $\mathrm{NiSO}_{4}+\mathrm{NaCl}$ & 28.9 \\
MIBK & $\mathrm{NiCl}_{2}+\mathrm{NH}_{4} \mathrm{SCN}$ & 0.11 \\
TIOA & $\mathrm{NiCl}_{2}$ & 1.74 \\
TIOA & $\mathrm{Ni}_{\left(\mathrm{NO}_{3}\right)_{2}}$ & 0.50 \\
MIBK & $\mathrm{NiSO}_{4}+\mathrm{NH}_{4} \mathrm{SCN}$ & 0.08. \\
\hline
\end{tabular}
removing pertechnate from both nickel chloride and buffered sulfate + chloride electrolytes at near-neutral $\mathrm{pH}$. This indicates that research to profile extraction of technetium as a function of $\mathrm{pH}$ should be performed as a part of overall system optimization. 


\section{Research Needs}

The results obtained with microsystems and discussed in Chapters 2 and 3 indicate the probability that industrial nickel electrowinning and uranium purification technologies can be adapted recover DOE nickel scrap. The challenge is somewhat different because radiologically contaminated nickel feedstock approaches the purity of high grade commercial material. However, to meet existing and anticipated de minimus standards, radiological contaminants must be reduced from a few $\mathrm{mg} / \mathrm{kg}$ to levels well below 0.1 $\mathrm{mg} / \mathrm{kg}$. A successful recovery process must use industrially proven unit processes to reach remarkable levels of product purity.

\section{Separation needs}

Even if the level of product nickel purity is remarkable, the actual reduction of contaminants is not that comparatively high: a factor of 25 to 10,000, depending on use. Conventional nickel matte feedstock is $20-40 \%$ nickel; the product is typically $99.9 \%$ or better. Assuming $100 \%$ nickel recovery, contaminants are reduced by factors of 1,500 to 4,000. Industry also recovers most feedstock contaminants - cobalt, copper, precious metals, iron - as high purity products.

How do the separations needs for radiological scrap compare with conventional process technology? As shown in Fig. 4.1, the Falconbridge nickel refinery is a complicated operation which maximizes the yield and purity of a number of products. This modern electrowinning process, which uses chlorine gas from the cells to dissolve matte feedstock, minimizes environmental impact and personnel requirements.

The purity of DOE's scrap, combined with the need to recover only one major process product, could permit drastic simplification of the process. The major Falconbridge process steps needed are designated in Fig. 4.1 by a bold solid border; unnecessary steps are indicated by dashed borders. A simplified process flow diagram is shown in Fig. 4.2.

The same solvent extractant, triisooctylamine, used to separate cobalt from nickel electrolyte is capable of extracting both technetium and actinides from highly acid organic aqueous phases. As discussed earlier, distribution coefficients for this and related systems range between 10 and 4,700, depending on the composition of the two phases. Selectivity against nickel is typically quite high, although it can be decreased if addition of compounds which prevent development of a third phase is required. Third phase formation has been minimized at Falconbridge by simply operating the process near $60 \mathrm{C}$.

For the projected process, what level of extractant performance will be required? Fig. 4.3 shows the effects of varying numbers of stages, distribution coefficients, and relative amounts of extractant and aqueous. From these, it appears that, with less than ten stages and with expected levels of contaminant extraction into backwash, even very low distribution coefficients will provide adequate product purity.

Similar arguments can be made for the ion exchange process. The separations requirements are well within the envelope characteristic of conventional industrial processes. Because of the very low contaminant levels, ion exchange can be used both for the radiological separation and for polishing - removing the last traces of contaminants and extractants. 


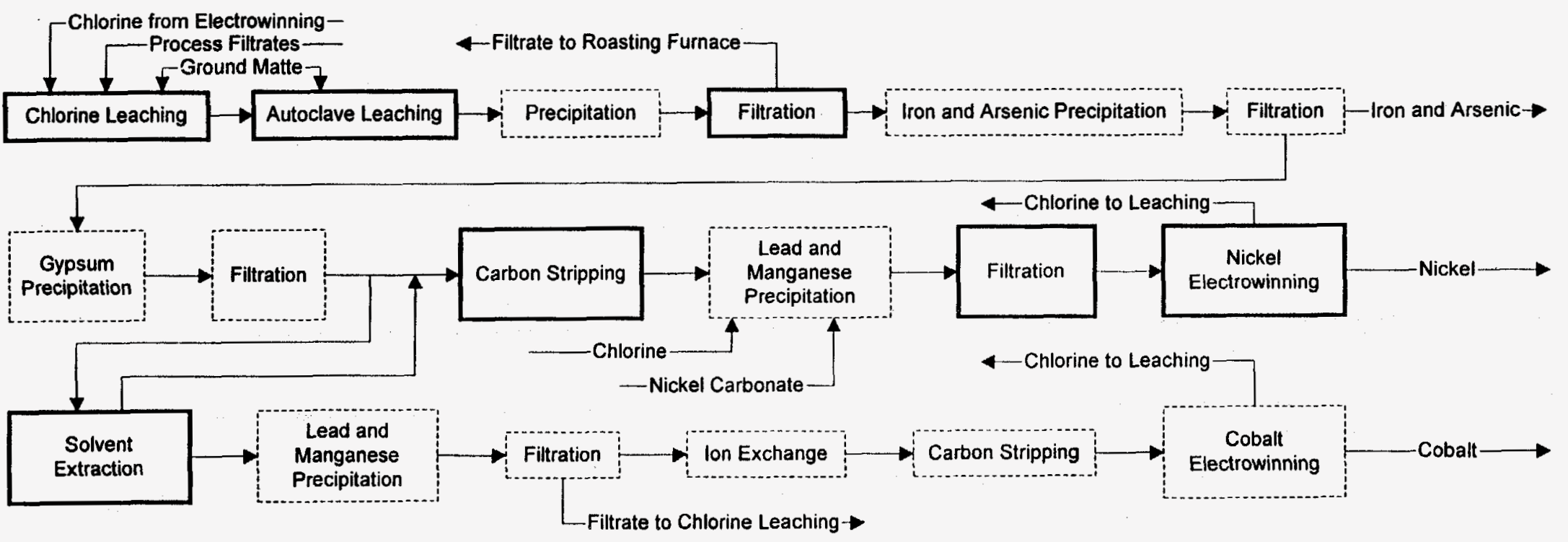

No

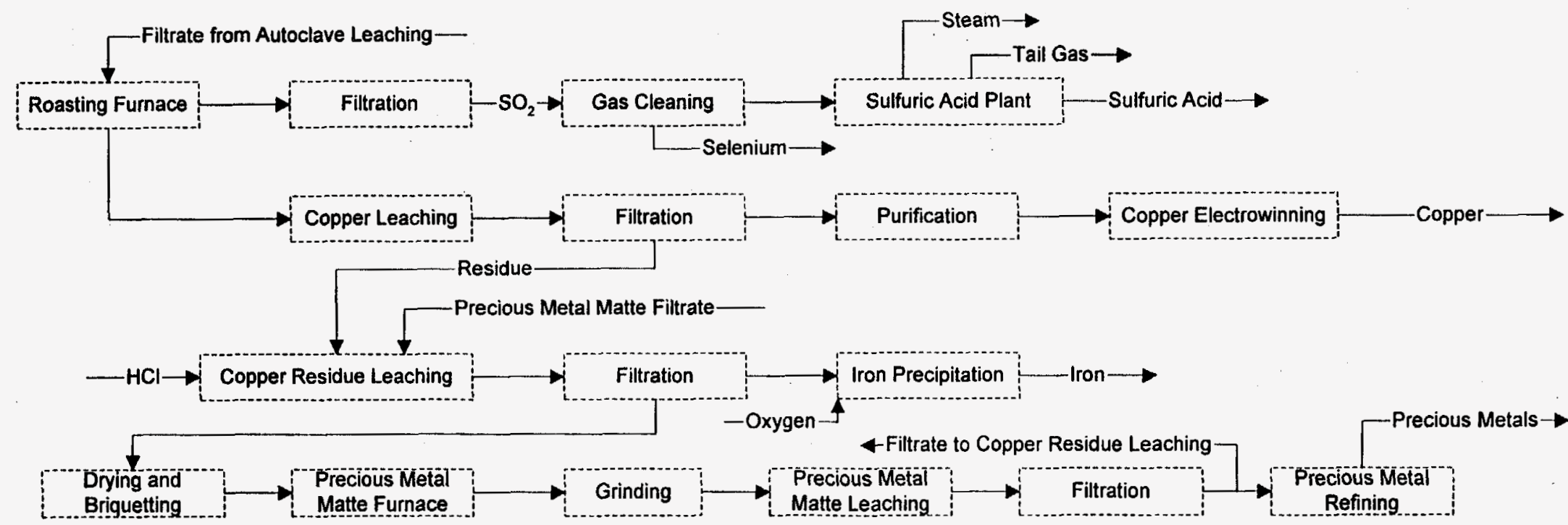

Fig. 4.1. Falconbridge Nickel Refinery chlorine-based process. Modified from: Stensholt and coworkers 1988. 


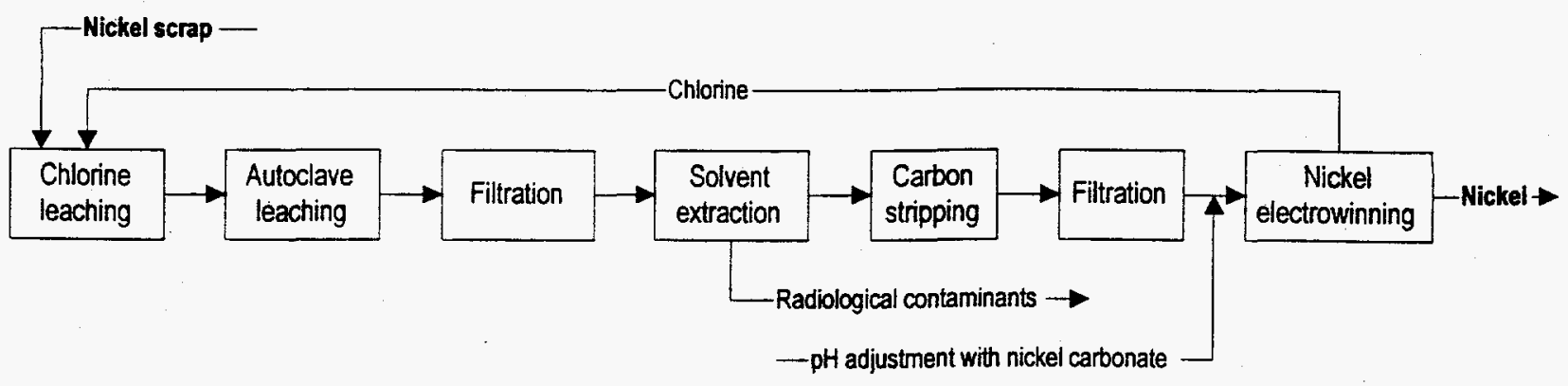

Fig. 4.2. Proposed nickel electrowinning process

\section{Gaps in process knowledge}

Most of the earlier research performed on technetium and actinide separations has used acid aqueous solutions. However, in the proposed process, acid nickel electrolytes will form the aqueous phase. Although preliminary extractions and industrial experience with related systems - Falconbridge uses a similar system to extract cobalt from nickel electrolyte - indicate that these are likely to be effective, the technology base required to support engineering evaluation of these process systems has not been developed.

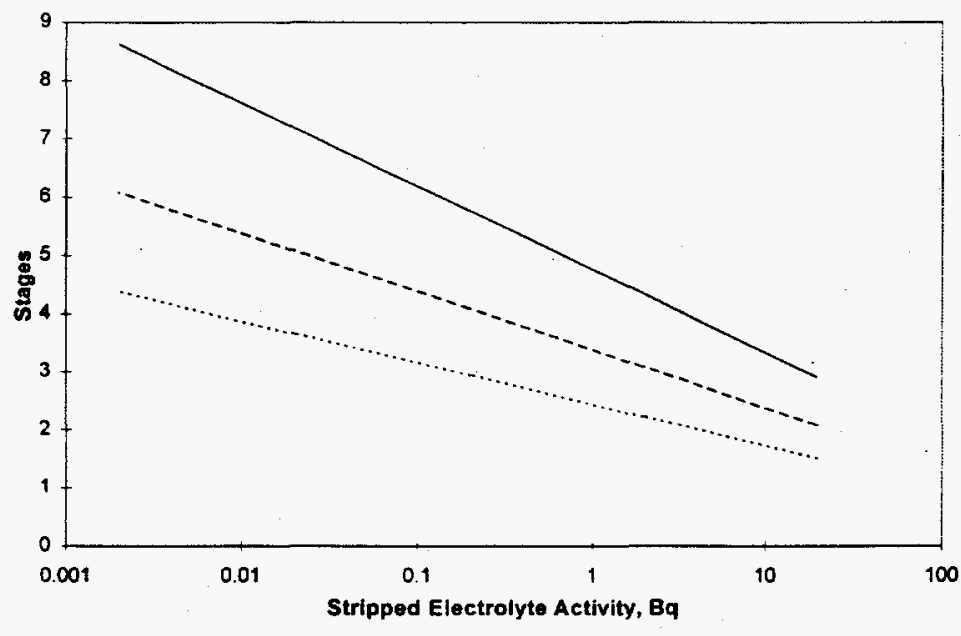

Fig. 4.3. Theoretical stages required to strip $2650 \mathrm{~Bq} / \mathrm{g}{ }^{99} \mathrm{Tc}$ from nickel electrolyte at $K_{d}=\mathbf{5 0}$. Organic to aqueous ratios: $0.1,-; 0.2,---0.5, \ldots$.
Separation of actinides and technetium by ion exchange has similarly been studied in acid solutions and in acid solutions containing alkali metals. However, we have been unable to find studies reporting ion exchange separations of actinides and technetium from acid nickel chloride solutions. To provide a basis for overall system development, these data will be required. Additionally, new ion exchange resin types, such as macroporous resins, could be used effectively in the proposed process. These should be evaluated.

Results from several other areas will be required to support scale-up. First, both actinides and technetium can take on several different valence states, depending on the potential and chemistry of the aqueous solution. Second, there is a need to evaluate the kinetics of nickel dissolution by chlorine. Dissolution is exothermic and the heat generated during this step is used to increase the rate of reaction. However, the second, or autoclave, dissolving step should be evaluated because pure nickel may have different dissolution patterns than a mixed-metal matte and because the matte itself contains other anions, most notably sulfides, which can affect dissolution rates. Pretreatment and any preprocess decontamination should also be evaluated for effect on dissolving and subsequent 
processing. For these reasons, understanding the kinetics, energy balances, and solution chemistry involved in dissolving Paducah nickel ingots (and small sections) is critical to development of an efficient process.

As studies progress, there is also a need to increase the duration of individual plating and solvent extraction runs. This serves the dual purpose of improving the quality of the knowledge base supporting engineering development and providing a better understanding of any problems that may arise during long-term operation or as a result of maximizing electrolyte and solvent recycle.

This process will recover and concentrate actinides (primarily uranium) and technetium. Although, based on DOE analysis of Paducah nickel buttons, relatively small amounts of radiological contaminants per se are expected. Although the amounts are small, minimization of the total amount of radiological waste is paramountl to the success of this process. The backwash and subsequent concentration stages will be optimized to produce concentrates which be finally disposed as generated using DOE approved methods for low level solid waste. 


\section{References}

American Public Health Association; American Water Works Association; and Water Pollution Control Federation. 1976. Standard methods for the examination of water and wastewater, 14th ed. Washington DC: American Public Health Association.

Barber, E. J.; Butler, T. R.; DeVan, J. H.; Googin, J. M.; Taylor, M. S.; Dyer, R. H.; and Russell, J. R. 1991. Investigation of breached depleted $U F_{6}$ cylinders. Oak Ridge National Laboratory report ORNL/TM-11988.

Barber, E. J.; DeVan, J. H.; Googin, J. M.; Taylor, M. S. 1994. Investigation of breached depleted $U F_{6}$ cylinders at the K-25 site. Oak Ridge National Laboratory report ORNL/TM-12840.

Beranova, H., and Tejnecky, M. 1972. Partition chromatography of uranium and fission products on porous styrene-divinylbenzene copolymer. Collected Czechosolvakian Chemical Communications 37: 3579-3589.

Bouboulis, C. J. 1979. Diluents in the separation of cobalt and nickel. CIM Special Volume 21(1): 32-39.

Boutin, P., and F. W. Melvanin. 1967. Method for the extraction of minerals. U. S. patent $3,295,932$.

Compere, A. L.; Griffith, W. L.; Hayden, H. W.; Johnson, J. S., Jr.; and Wilson, D. F. 1994. Contaminated nickel scrap processing. Oak Ridge National Laboratory report ORNL/TM-12900.

Department of Energy. 1995. Proposed sale of radioactively contaminated nickel ingots located at the Paducah Gaseous Diffusion Plant, Paducah, Kentucky. DOE draft environmental assessment DOE/EA-0994.

Diamond, R. M., and D. C. Whitney. 1966. Resin selectivity in dilute to concentrated aqueous solutions. In Ion Exchange, ed. J. A. Marinsky, pp. 277-351. New York: Marcel Dekker.

Green, D. W., ed. 1984. Perry's chemical engineers' handbook, 6th ed, pp. 15-14 to 15-18. New York: McGraw-Hill Book Company, Inc.

Griffith, W. L.; Jasney, G. R.; and Tupper, H. T. 1952. The extraction of cobalt from nickel in a pulse column. Massachusetts Institute of Technology Engineering Practice School report K-972.

Itzkovitch, J. I., and W. A. Rickelton. 1982. Procede d'extraction par solvant pour la recuperation de l'uranium. 1982. French patent 8209239.

Itzkovitch, I. J., and W. A. Rickelton. 1983. Solvent extraction process for the recovery of uranium. Canadian patent 1,157,278.

Keder, W. E. 1962. Extraction of tetra- and hexavalent actinides from hydrochloric acid by tri-noctylamine in xylene. Journal of Inorganic and Nuclear Chemistry 24: 561-570.

Kessinger, G. F. 1993. Evaluation of the electrorefining technique for the processing of radioactive scrap metals. Idaho National Engineering Laboratory report WINCO-1165.

Kraus, K. A., and F. Nelson. 1955. Anion exchange studies of the fission products. In Proceedings of the International Conference on the Peaceful Uses of Atomic Energy I, Vol. 7, pp. 113-136. New York: United Nations.

Kraus, K. A., and F. Nelson. 1958. Metal separation by ion exchange. In Symposium on Ion Exchange and Chromatography in Analytical Chemistry, pp. 27-57. American Society for Testing Materials special technical publication 195. (See esp. Fig 11.)

Kraus, K. A.; Nelson, F.; Clough, F. B.; and Carlston, R. C. 1955. Anion exchange studies. XVI. Adsorption from lithium chloride solutions. Journal of the American Chemical Society 77: 1391. 
Kraus, K.A.; Phillips, H. O.; and Nelson, F. 1962. Some applications of radioisotopes in physical chemistry - two phase equilibria and packed-column techniques. In Proceedings of the 1960 LAEA Copenhagen Conference on "Radioisotopes in the Physical Sciences and Industry", Vol. III, pp. 387-406. Vienna: International Atomic Energy Agency.

Müller, W. 1967. The extraction of actinides by alkyl-substituted ammonium salts: Actinides Reviews 1(1): 71-119.

QingJiang, C.; Aarkrog, A.; Dahlgaard, H.; Nielsen, S. P.; Holm, E.; Dick, H.; Mandrup, K. 1989. Determination of Technetium-99 in environmental samples by solvent extraction at controlled valence. Journal of Radioanalytical and Nuclear Chemistry, Articles 131 (1): 171-187.

Ritcey, G. M. 1969. Application of solvent extraction to common base metals (a review). Canadian Mining Journal 90(6): 73-78.

Schultze, L. E.; Bauer. D. J.; and Morimoto, M. T. 1981. Extracting uranium from carbonaceous ores. Burea of Mines report 8580.

Sefton, V. B.; Fox, R.; and Lorenz, W. P. 1989. Method of separately recovering metal values of petroleum refining catalyst. U.S. patent $4,861,565$.

Stensholt, E. O.; Zachariasen, H.; and Lund, J. H. 1986. Falconbridge chlorine leach process. Transactions of the Institute of Mining and Metallurgy, Section C: C10-C16.

Stensholt, E. O.; Zachariasen, H.; and Lund, J. H. 1986. The Falconbridge chlorine leach process. In Nickel Metallurgy Symposium, Proceedings of the 25th annual conference on metallurgy, vol. 1, ed. Ozberk, E., and S. W. Marcuson, pp. 442-463. Canadian Institute of Mining and Metallurgy: Montreal, Quebec.

Stensholt, E. O.; Zachariasen, H.; Lund, J. H.; and Thornhill, P. G. 1988. Recent improvements in the Falconbridge nickel refinery. In Extractive metallurgy of nickel and cobalt, ed. G. P. Tyler and C. A. Landholt. London: The Metallurgical Society.

Sundamurthi, N. M., and V. M. Shine. 1991. Extraction and separation of uranium and lead with liquid anion-exchangers. Talanta 38(2): 223-228.

Wu, K.-L., and Lo, J.-M. 1990. Separation of uranium mixing with its decayed nuclides and its activated nuclides. Journal of the Chinese Chemical Society 37: 435-441. 


\section{Materials and Methods}

Potentiometric polarization studies. These studies used a glass cell, shown in Fig. 2.1, which contained three compartments separated by glass frits. One compartment housed a $1 \mathrm{~mm}$ nickel wire working electrode with $1 \mathrm{~mm}$ exposed; another, the $2 \mathrm{~mm}$ nickel wire control electrode with $3 \mathrm{~cm}$ exposed; and the third, a standard Corning 476002 calomel reference electrode.

The system was controlled by an EG\&G model 173 potentiostat with a model 179 digital coulometer. This supplied a voltage to the working electrode relative to the reference electrode. A personal computer fitted with Strawberry Tree analog input and analog output boards running under MSDOS was used to vary the voltage of the potentiostat and record its outputs, particularly the voltage and current. Using "Workbench" software, electrode outputs were recorded at $1 \mathrm{sec}$ intervals.

Starting from the voltage where the cell current was zero, we made both positive and negative runs at $25 \mathrm{C}$. The reduction runs were made to $-1.4 \mathrm{~V}$; the oxidation runs, to +0.5 $\mathrm{V}$. We approached the zero cell current from both directions. The voltage ramp scan rate was $1 \mu \mathrm{V} / \mathrm{sec}$. Both control and working electrodes were magenetically stirred. A nitrogen gas purge deoxygenated the solution in the working electrode chamber. Provision for magnetic stirring control and working electrode compartments was made.

Solutions tested included the sulfate-chloride-borate electrolyte used in conventional electrorefining operations and other electrolytes (chloride, thoiocyanate, nitrate) likely to be used in the proposed electrowinning processes.

Plating quality and current efficiency studies. For these studies, the working electrode was replaced with a $1 \mathrm{~cm}^{2} \times 2 \mathrm{~mm}$ thick nickel electrode supported by $1 \mathrm{~mm}$ nickel wire. Sufficient potential was applied to maintain a current density of $17 \mathrm{~mA} / \mathrm{cm}^{2}$ at $-1.6 \mathrm{~V}$. These conditions are comparable to those used in conventional electrowinning operations. Approximately 200 coulombs were used for each sample.

Nitrite determination. To a $50 \mathrm{ml}$ sample at $\mathrm{pH} 7,1 \mathrm{ml}$ of a $1 \%$ solution of sulfanilamide in 1:10 concentrated $\mathrm{HCl}$ was added as described in detail in the 14th edition of Standard Methods for the Examination of Water and Wastewater (American Public Health Association 1976, pp. 434-437). After 2-8 minutes, $1 \mathrm{ml}$ of a $1 \mathrm{~g} / \mathrm{l}$ solution of $N$-(1napthyl)-ethylenediamine dihydrochloride was added. After at least ten minutes, an aliquot was placed in a $1 \mathrm{~cm}$ pathlength quartz cuvette and absorbance was measured at $543 \mathrm{~nm}$.

Reagents. Sodium chloride was Baker Analyzed Reagent grade; ammonium thiocyanate was Baker Analyzed Reagent grade; tribasic sodium phosphate dodecahydrate was Fisher ACS grade; the ammonium citrate was MC/B ACS grade; nickelous sulfate was Baker Analyzed Reagent grade; nickelous chloride was Baker Analyzed Reagent grade; nickelous nitrate was Baker Analyzed Reagent grade; TIOA, or triisoocytlamine, was Aldrich; N-(1napthyl)-ethylenediamine dihydrochloride was EM reagent grade; sulfanilamide was J. T. Baker purified grade; and the 3-methyl-2-butanone was Aldrich. Scintillation cocktail was Packard Ultima Gold XR. The nickel wire was Aldrich 99.995\% Ni and the $2 \mathrm{~mm}$ thick sheet was Alfa $99.999 \% \mathrm{Ni}$. 
Solvent extraction of cobalt. Four ml. each of electrolysis solution and extractive solvent were pipetted into a teflon-sealed $10 \mathrm{ml}$ screwcap tube. A spike of $100 \mu \mathrm{l}$ of 0.01 $M \mathrm{CoCl}_{2}$ was then added. The samples were capped and gently mixed at $25 \mathrm{C}$ for 5 mintes. They were then allowed to stand for a few minutes to permit phase separation. The cobalt in the aqueous phase was then determined by complexation with thiocyanate and reextraction into 3-methyl-2-butanone. The colored cobalt thiocyanate complex was measured by absorbance at $720 \mathrm{~nm}$. Sample values were determined by comparison to a calibration curve.

Solvent extraction of pertechnate. Two ml each of electrolysis solution and extractive solvent were pipetted into a teflon-sealed $10 \mathrm{ml}$ screwcap tube. A pertechnate spike containing roughly $24,000 \mathrm{cpm}$ in $10 \mu \mathrm{l}$ was then added. . The tube threads were wrapped with teflon pipe tape and the cap screwed on. After gentle mixing at $23 \mathrm{C}$ for 15 minutes, the samples were allowed to stand for a few minutes to permit phase separation. Aliquots of aqueous and organic phases were removed to a transfer vial. Subsequently, $0.5 \mathrm{ml}$ of each phase was placed in a scintillation vial and mixed with $6 \mathrm{ml}$. of Packard Ultima Gold XR scintillation cocktail. A small quantity of Triton X-100 $(0.1 \mathrm{ml})$ was added to improve phase separation of sulfate-containing aqueous samples. Prepared samples were then counted using a Packard Tricarb TR-2700 scintillation counter. 


\section{INTERNAL DISTRIBUTION}

\section{1-2. Central Research Library}

3-4. Laboratory Records Department

5. Laboratory Records, ORNL-RC

6. ORNL Patent Section

7-9. M\&C Records Office

10. D. J. Bostock

11-20. G. M. Brown

21-30. A. L. Compere

32. R. H. Cooper

33. D. F. Craig

34. J. R. Distefano

35. D. E. Fain
36-45. W. L. Griffith

46. M. R. Guerin

47-56. H. W. Hayden

57. W. P. Huxtable

58. R. A. Jenkins

59. J. S. Johnson, Jr.

60. J. W. Koger

61. A. S. Loebl

62-63. A. P. Malinauskas

64. M. L. Poutsma

65-74. D. F. Wilson

\section{EXTERNAL DISTRIBUTION}

75. S. E. Bigger, U. S. DOE, Carlsbad Operations; P. O. Box 3090; Carlsbad NM 88221.

76. E. G. Comesty; ORNL Site Manager; Department of Energy; Oak Ridge National Laboratory; Post Office Box 2008; Oak Ridge, Tennessee 37831-6269

77-78. J. L. Harness, U. S. DOE, Oak Ridge Operations, Box 2001, Oak Ridge TN 37831

79-82. J. M. Hyde, EM-541, U. S. Department of Energy, Forrestal Building, 100 Independence Avenue, Washington DC 20585

83. J. O. Moore, U. S. DOE, Oak Ridge Operations, Box 2001, Oak Ridge TN 37831

84. Transportation Manager, U. S. DOE, Carlsbad Operations; P. O. Box 3090; Carlsbad NM 88221.

85-86. DOE Office of Scientific and Technical Information, P. O. Box 62, Oak Ridge TN 37831

For distribution by microfice as shown in DOE/OSTI-4500R75, Distribution Category UC-902 